\title{
Monitoring Thermal and Non-Thermal Treatments during Processing of Muscle Foods: A Comprehensive Review of Recent Technological Advances
}

\author{
Abdo Hassoun ${ }^{1, *}{ }^{\circledR}$, Shikha Ojha ${ }^{2,3}$, Brijesh Tiwari ${ }^{2}$, Turid Rustad ${ }^{4}{ }^{\circledR}$, Heidi Nilsen ${ }^{1}$, \\ Karsten Heia ${ }^{1}$, Daniel Cozzolino ${ }^{5}\left(\mathbb{D}\right.$, Alaa El-Din Bekhit ${ }^{6}(\mathbb{D})$, Alessandra Biancolillo ${ }^{7}(\mathbb{D})$ and \\ Jens Petter Wold ${ }^{1}$ \\ 1 Nofima AS, Norwegian Institute of Food, Fisheries, and Aquaculture Research, 9291 Tromsø, Norway; \\ heidi.nilsen@nofima.no (H.N.); karsten.heia@nofima.no (K.H.); jens.petter.wold@nofima.no (J.P.W.) \\ 2 Department of Food Chemistry and Technology, Teagasc Food Research Centre, Ashtown, \\ D15KN3K Dublin, Ireland; sojha@atb-potsdam.de (S.O.); brijesh.tiwari@teagasc.ie (B.T.) \\ 3 Quality and Safety of Food and Feed, Leibniz Institute for Agricultural Engineering and Bioeconomy (ATB), \\ 14469 Potsdam, Germany \\ 4 Department of Biotechnology and Food Science, Norwegian University of Science and Technology, \\ 7941 Trondheim, Norway; turid.rustad@ntnu.no \\ 5 Centre for Nutrition and Food Sciences, Queensland Alliance for Agriculture and Food Innovation (QAAFI), \\ The University of Queensland, Brisbane QLD 4072, Australia; d.cozzolino@uq.edu.au \\ 6 Department of Food Science, University of Otago, Dunedin 9054, New Zealand; aladin.bekhit@otago.ac.nz \\ 7 Department of Physical and Chemical Sciences, University of L'Aquila, Via Vetoio, 67100 L'Aquila, Italy; \\ alessandra.biancolillo@univaq.it \\ * Correspondence: abdo.hassoun@nofima.no; Tel.: +47-930-73-906
}

Received: 9 September 2020; Accepted: 27 September 2020; Published: 28 September 2020

\begin{abstract}
Muscle food products play a vital role in human nutrition due to their sensory quality and high nutritional value. One well-known challenge of such products is the high perishability and limited shelf life unless suitable preservation or processing techniques are applied. Thermal processing is one of the well-established treatments that has been most commonly used in order to prepare food and ensure its safety. However, the application of inappropriate or severe thermal treatments may lead to undesirable changes in the sensory and nutritional quality of heat-processed products, and especially so for foods that are sensitive to thermal treatments, such as fish and meat and their products. In recent years, novel thermal treatments (e.g., ohmic heating, microwave) and non-thermal processing (e.g., high pressure, cold plasma) have emerged and proved to cause less damage to the quality of treated products than do conventional techniques. Several traditional assessment approaches have been extensively applied in order to evaluate and monitor changes in quality resulting from the use of thermal and non-thermal processing methods. Recent advances, nonetheless, have shown tremendous potential of various emerging analytical methods. Among these, spectroscopic techniques have received considerable attention due to many favorable features compared to conventional analysis methods. This review paper will provide an updated overview of both processing (thermal and non-thermal) and analytical techniques (traditional methods and spectroscopic ones). The opportunities and limitations will be discussed and possible directions for future research studies and applications will be suggested.
\end{abstract}

Keywords: analysis; fish; heat; HPP; infrared; MAP; meat; ohmic; process; quality; spectroscopy 


\section{Introduction}

Quality of fish and meat and other muscle food products depends heavily on processing and preservation methods applied after harvest or slaughter. Indeed, without adequate treatment and preparation, muscle food products undergo rapid natural deterioration due mainly to microbial growth, oxidative reactions, and enzymatic autolysis. That is why a wide range of preservation techniques have been developed over the years [1]. Traditional thermal treatments such as roasting, boiling, grilling, and frying have been widely used for ages due to their availability and simplicity. The main purposes of thermal treatments are to cook food and enhance sensory properties and digestibility, to inactivate microorganisms and ensure food safety, and to extend the shelf life [2,3]. However, the application of high heat loads may lead to degradations and harmful effects on sensory and nutritional quality parameters of the treated products, especially in the case of muscle food products, which are known for their high sensitivity to heat treatments [4-6]. Muscle protein denaturation, lipid and protein oxidation, and loss in nutritional quality are among the well-known alterations that take place in muscle foods during thermal treatments [7-9]. Moreover, the constantly increasing consumer demand for fresh, safe, nutritious, and healthy food products, along with the novel consumption trends (e.g., minimally processed foods) have moved the food industry towards the development of novel and innovative thermal processing techniques $[10,11]$. In this regard, a number of techniques, such as microwave, radio frequency, ohmic heating, and infrared processing have become the center of interest of several recent studies [2,12-14].

Over the past few years, more advanced techniques have emerged aiming to meet consumer demands for high-quality products, with extended shelf life, improved safety, and enhanced process efficiency. With these in mind, a number of non-thermal treatments including, modified atmosphere packaging (MAP), high pressure processing (HPP), pulsed electric field (PEF), ultrasound (US), and cold plasma, among others [15-23] have grown in popularity over the last few years. Some of these techniques are already in use in the food industry, while others are still under development and require further improvement. Several studies have demonstrated that such preservation approaches are energy-efficient and allow inactivating microorganisms and enzyme activity in food products without compromising on their sensory quality attributes $[10,11,15,24,25]$. Extensive information about the application of non-thermal treatments in fish $[15,16,26,27]$ and meat $[10,28-30]$ can be found in the referred literature.

On the other hand, most of the analytical methods used to assess changes in fish and meat during or after processing are based on sensory and microbiological analysis, as well as a number of physicochemical approaches [10,31,32]. Although sensory and microbiological measurements are among the most used techniques to determine the shelf life of most food products, these techniques are laborious and expensive as it usually takes from several hours to several days in order to obtain the results. Besides, the destructive nature of such measurements makes them unattractive for routine monitoring in the modern food industry. These limitations apply also to a number of physico-chemical methods (e.g., measurements of oxidation products, volatile compounds, drip loss, etc.). On the other side, spectroscopic assessment methods such as visible and infrared-based techniques, fluorescence, Raman, and NMR spectroscopy have shown the potential to overcome challenges related to traditional assessment methods [31,33,34]. In addition, recent progress and advances in the spectroscopic field has led to the development of hyperspectral imaging, enabling both spectral and spatial information from the scanned samples [35-37]. Given the aforementioned features, the application of spectroscopic techniques has become a research hotspot and the number of scientific publications dealing with topics related to spectroscopy has been increasing rapidly during the last years (Figure 1). 


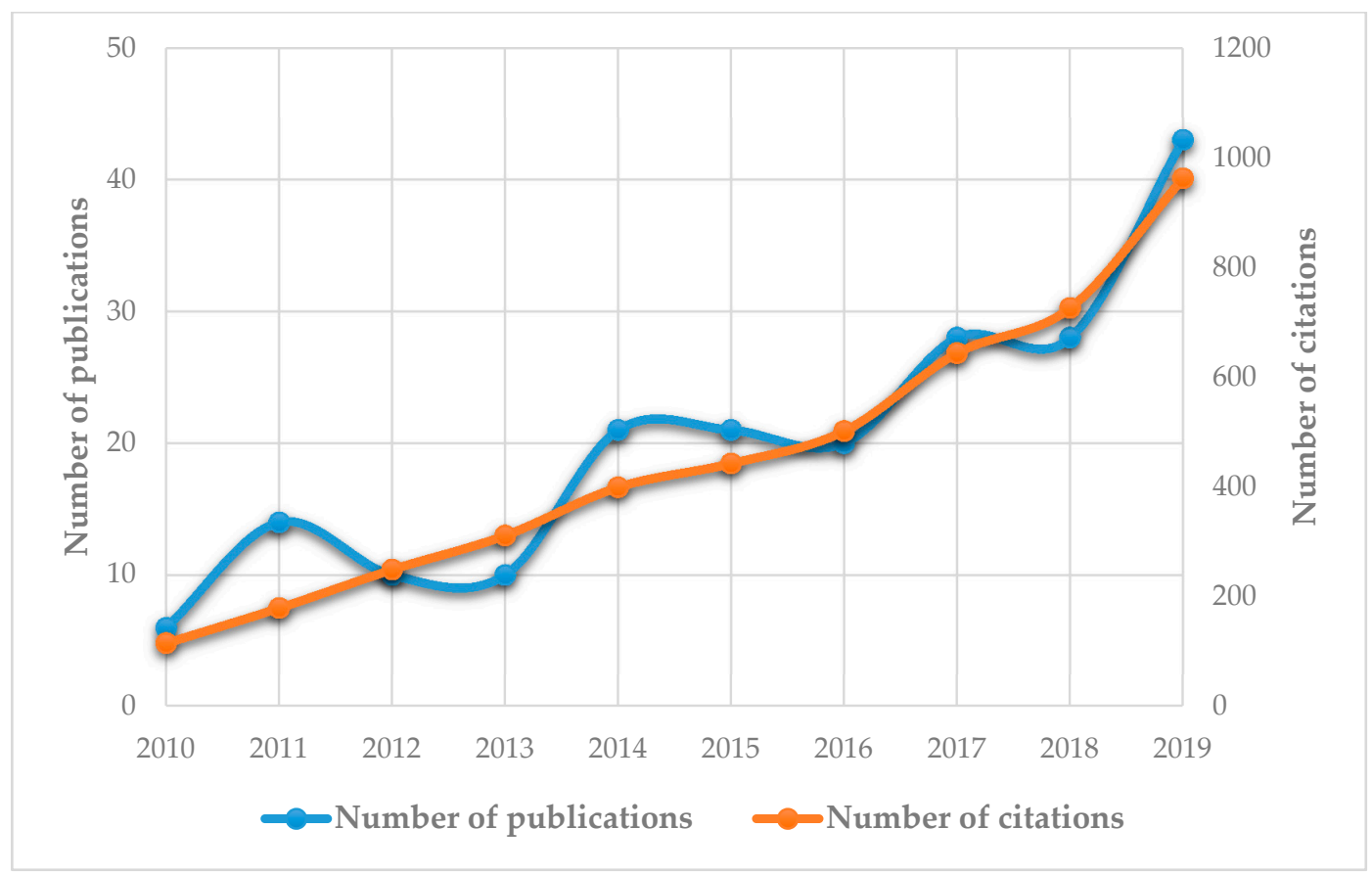

Figure 1. Number of publications (blue line) and citations (red line). Data were obtained using Scopus (August 2020). Research criteria: TITLE-ABS-KEY (thermal treatment) OR (non-thermal treatment) OR (ohmic heating) OR (microwave heating) OR (radio frequency heating) OR (infrared heating) OR (pulsed electric field) OR (modified atmosphere packaging) OR (cold atmospheric plasma) OR (ultrasound) OR (high pressure processing) AND (spectroscopy) AND (fish) OR (meat) OR (muscle food).

Several review papers have been published recently dealing with either thermal and non-thermal processing treatments $[15,19,38,39]$ or with analytical methods [34,35,40-43]. However, to the best of our knowledge, this is the first review paper that covers a wide range of both processing and preservation treatments as well as assessment methods used to monitor quality changes in muscle foods occurring during or following the application of treatments. The manuscript will first discuss the recent trends and applications of both thermal and non-thermal treatments used for maintaining quality and prolonging shelf life of muscle foods. The use of spectroscopic techniques as alternative tools to traditional analytical methods will be then extensively highlighted.

\section{The Main Thermal and Non-Thermal Processing Techniques}

\subsection{Thermal Processing}

Traditional thermal processing methods (e.g., boiling, frying, roasting, grilling, smoking) provide organoleptically acceptable and well-tasting products, but have many drawbacks, such as limited heat penetration, long processing time due to slow transfer of heat, nonhomogeneous distribution of heat, leading to overheating or underheating problems $[8,10,44]$. To limit these challenges, some novel approaches have been tested such as the use of exchanging agitation during thermal processing (e.g., Shaka technology) or the use of surface pasteurization $[4,45,46]$. A number of novel processing techniques have been emerged in recent years due to their advantages over traditional thermal treatments (Table 1). The main tested techniques include microwave and radio frequency heating, ohmic heating, and infrared heating. One of the main advantages of novel thermal processing compared to traditional thermal treatments is the fact that the treated products are heated internally and not through the surface, resulting in fast volumetric heating $[2,12,14]$. 
Table 1. Some examples of thermal technologies applied for muscle food processing.

\begin{tabular}{|c|c|c|c|}
\hline Muscle Food Product & Thermal Treatments & Main Findings & Reference \\
\hline Sea bream surimi & Microwave & $\begin{array}{l}\text { Microwave- and water bath-treated samples demonstrated better gel properties (stronger gel } \\
\text { with finer texture and increased WHC, etc.) than samples heated only with microwave }\end{array}$ & [47] \\
\hline Sea bream surimi & Microwave & $\begin{array}{l}\text { Surimi paste with a thickness of } 2 \mathrm{~cm} \text { of surimi gave the highest WHC, lowest cooking loss, } \\
\text { uniformity of temperature distribution, higher tensile force, and whiteness }\end{array}$ & [48] \\
\hline Sturgeon & $\begin{array}{l}\text { Microwaving and other } \\
\text { traditional methods }\end{array}$ & $\begin{array}{l}\text { Higher proteins and lipid oxidation in roasted and fried samples than those cooked under less } \\
\text { intense cooking conditions (boiling, steaming, and microwaving) }\end{array}$ & [49] \\
\hline Atlantic salmon & $\begin{array}{l}\text { Microwave and } \\
\text { conventional pasteurization }\end{array}$ & $\begin{array}{l}\text { Combination of } \mathrm{CO}_{2} \text { with heating increased shelf life compared to heating (with microwave or } \\
\text { conventional pasteurization) without presence of } \mathrm{CO}_{2} \text { in vacuum-package }\end{array}$ & [50] \\
\hline Grass carp & Microwave & $\begin{array}{l}\text { Increased microwave power and treatment time induced a decrease in solubility and an increase } \\
\text { in turbidity, indicating a more aggregation of proteins }\end{array}$ & [51] \\
\hline Cod & Convection oven & $\begin{array}{l}\text { Development of a model to predict temperature and moisture concentration based on both heat } \\
\text { and mass transfer during cooking }\end{array}$ & [52] \\
\hline European sea bass & $\begin{array}{l}\text { Microwave and } \\
\text { conventional oven }\end{array}$ & $\begin{array}{l}\text { Conventional oven backing gave higher abundances of volatile compounds than microwave } \\
\text { cooking and salt-crusted oven baking }\end{array}$ & [53] \\
\hline Shrimp & Ohmic heating & $\begin{array}{l}\text { Ohmic heating was applied as a blanching method prior to maturation. The impact of ohmic } \\
\text { heating and high pressure on peelability, thermal and structural properties of shell and meat of } \\
\text { shrimp were discussed }\end{array}$ & [54] \\
\hline Pork batters & Ohmic heating & $\begin{array}{l}\text { Ohmic heated samples had a more uniform temperature distribution compared to those heated } \\
\text { in a traditional water bath, and the overall results suggested that ohmic heating was suitable for } \\
\text { meat processing }\end{array}$ & [55] \\
\hline Turkey breast rolls & Radio frequency heating & $\begin{array}{l}\text { Radio frequency heating allowed a reduction of processing time from } 150 \text { min (traditional steam } \\
\text { processing) to only } 40 \text { min. Radio frequency heated samples had lower redness values and lipid } \\
\text { oxidation rates compared to the other samples }\end{array}$ & [56] \\
\hline Pork hams & Radio frequency heating & $\begin{array}{l}\text { Radio frequency heating enabled } 50 \% \text { reduction of processing time. The best results were } \\
\text { obtained by combining traditional steam heating with radio frequency method, with little } \\
\text { differences in sensory quality being observed compared with the traditional steam process }\end{array}$ & [57] \\
\hline Beef steaks & Radio frequency heating & $\begin{array}{l}\text { The developed cooking protocol was applicable to the whole steaks under real processing } \\
\text { conditions. Thermal inactivation of Shiga toxin-producing Escherichia coli was more effective at } \\
655^{\circ} \mathrm{C} \text { with a } 5.0 \text { log reduction }\end{array}$ & [58] \\
\hline Beef meatballs & Ohmic-infrared heating & $\begin{array}{l}\text { Infrared heating improved the appearance of the ohmically precooked meatball samples, and the } \\
\text { obtained results were affected by the power applied and the distance between the infrared source } \\
\text { and the sample surface }\end{array}$ & [59] \\
\hline Beef meatballs & Ohmic-infrared heating & $\begin{array}{l}\text { Ohmically precooked samples followed by infrared heating could improve the microbiological } \\
\text { safety and reduce the risk of foodborne illnesses }\end{array}$ & {$[60]$} \\
\hline Chicken nugget & Infrared heating and frying & $\begin{array}{c}\text { Compared to deep fat frying method, infrared heated samples had significantly lower fat content, } \\
\text { while the color, texture, and other sensory properties were similar to those cooked with the deep } \\
\text { fat frying }\end{array}$ & [61] \\
\hline
\end{tabular}


Microwave heating is an efficient dielectric heating technique that has attracted much interest from both research and industry due to the high heating rate and rapid processing time $[14,32,62]$. The electromagnetic waves produced inside the microwave oven cause water molecules in the food to vibrate, producing heat $[14,19]$. Several studies have reported that the performance of microwave heating overpasses that of traditional heating methods. For example, a recent study showed that microwaving chicken thigh and breast meats results in better quality attributes of the cooked products compared to conventional ovens [63]. In another study, microwave cooking was found to improve saltiness perception of grass carp meat, with lower cooking loss and shear force being observed compared to traditional water bath [64]. However, it is well-known that nonuniform temperature distribution is one of the main drawbacks related to the use of microwave [14,44]. Recently, a number of microwave-assisted food processing techniques have been tested in order to overcome the limitations associated with traditional microwaving, providing the path for a promising future in process optimization [62].

Radio frequency heating is another dielectric heating technique that has drawn attention in recent years. As for microwaving, the radio frequency heating provides a fast and volumetric heating, but the difference here is that the heat is generated by friction between charged ions, which causes the entire water-containing material to be heated simultaneously $[12,19,65]$. A radio frequency treatment combined with circulating tap water was developed for quick and uniform heating of packaged whole Pacific sauries [66]. The results showed 5-log reduction of Bacillus subtilis spores in the saury with less color changes in the meat, and a softer backbone compared with conventional heating. An earlier study demonstrated that radio frequency cooking of turkey meat was four times more rapid when compared to steam cooking, while no detectable sensory differences were observed between samples [56]. Nevertheless, the use of radio frequency heating is still limited to only a few industrial applications, such as thawed frozen products $[67,68]$.

Ohmic heating occurs when an alternating electrical current is passed through the food, producing an internal generation of heat $[2,24,69]$. Compared with traditional heat processing, ohmic heating is advantageous with respect to cooking time. In addition, this innovative technique is environmentally friendly, efficient in terms of energy conversion, does not require heat transfer surfaces, and can reduce temperature gradients and increase cooking yield $[10,24,70]$. Although ohmic heating has shown its effectiveness in inhibiting microbial growth in many applications related to muscle foods $[55,69,71]$, several aspects related to the use of this technique for manufacturing safe food need to be investigated [70].

Infrared heating involves exposure of food to infrared electromagnetic radiation (i.e., the radiation falling between the visible and microwaves ranges). Most food components absorb this kind of radiation, thus the technique is characterized by several features including uniform heating, short heating time, and energy-saving, just to mention a few [13,19,72]. Nevertheless, the weak penetration of infrared light limits its wider application as a heat processing method; therefore up to date, infrared heating has been used for materials of thin layer or as a supplementary heating source for muscle foods that have been already heated using ohmic heating or other heat processing techniques $[19,59,73,74]$.

\subsection{Non-Thermal Processing}

Food processing technologies that do not use direct heating as the main means to inactivate microorganisms and enzymes in food products are broadly recognised as non-thermal technologies. Non-thermal technologies are often classified as technologies that are capable of achieving microbial inactivation at sub lethal temperature. Contrary to thermal technologies, non-thermal processing has minimal effects on the texture, color, aroma, taste, and nutritional value of food products while achieving food objectives and meeting consumer demands for fresh-like, minimally processed, and preservative-free foods. Non-thermal techniques including high pressure processing (HPP), ultrasound, pulsed electric field (PEF), and cold atmospheric plasma (CAP) as well as packaging 
technology, particularly modified atmospheric packaging (MAP) have been exploited for niche applications in muscle food processing.

In the muscle food processing, HPP involving pressures in the range of 100-600 MPa is mainly employed to extend shelf-life, improve the food safety profile, and to alter key quality parameters, including texture, color, and water holding capacity of muscle food products [75,76]. The inactivation effects of HPP on microorganisms including yeasts, molds and bacteria and spores and shelf life extension of muscle food products are well documented in the literature (Table 2). The general inactivation mechanism of microorganisms by HPP is associated with a combination of several factors including changes in the cell membranes, cell wall, proteins, and enzyme-mediated cellular functions [77,78]. More recent studies have reported that the HPP treatment could improve tenderness and eating quality of meat $[79,80]$. Further, HPP can be employed to obtain a better texture and appearance for gels and gel-like fish products. High pressure shift, assisted or induced freezing and/or thawing of fish products can extend the shelf-life of frozen muscle food products while minimizing the adverse effects of freezing technology on the quality parameters [81-83].

Power ultrasound processing has emerged as an alternative non-thermal food processing technique for a range of applications. In the meat processing, ultrasound has shown potential for meat tenderization, acceleration of maturation and mass transfer, and shelf life extension of muscle products [84]. Additionally, ultrasound can assist in reducing salt usage in processed meats [85] and improve the emulsification and gelling properties, thus may allow reduction in usage of chemical additives such as phosphates [86]. Several studies have proven that the ultrasound can reduce brining time without affecting meat quality, whilst improving salt diffusion rates [87]. These ultrasonic effects can be explained by combination of cavitation phenomena, shear disruption, localized heating, and free radicals' formation.

CAP is a novel non-thermal technology which is effective against a wide range of microorganisms, including pathogens, spoilage bacteria, biofilms, and bacterial spores commonly associated with various foods including muscle food products. Plasma is composed of highly reactive species, including gas molecules, primarily composed of photons, ions and free electrons, neutral particles (atoms, molecules), activated and metastable species (NOx-), free radicals like reactive oxygen species (ROS), and reactive nitrogen species (RNS), which collectively attribute to its bactericidal properties. The plasma technique has recently been tested for surface decontamination on a range of muscle foods (Table 2). Recently, plasma has been reported as a novel source of nitrite, which is an important additive in the production of cured meat products [88].

PEF processing involves the application of short-time electric pulses causing permeabilization of cells, thus inducing several effects. Microstructural modifications in muscle foods after PEF treatment can improve techno functional properties such as water holding capacity and tenderness of the treated products [89]. Further, PEF can be utilized for increased extraction of high added-value compounds including protein from mussel and muscle food by-products [22].

MAP is a preservation method that involves manipulation of distribution and composition of the gaseous atmosphere inside a packaging container which can extend the shelf life of fresh and minimally processed foods. MAP combined with low temperature storage is being applied to muscle foods for decades and has remained one of the popular methods of shelf life extension, allowing the distribution of a consistent and cost-effective product to retail [90]. Carbon dioxide, oxygen, and nitrogen are the commonly used gases in MAP, along with trace amounts of carbon monoxide, argon, and helium. The gas composition depends on the product to be packed, for example high oxygen $(70-80 \%)$ is used for fresh meat to maintain the desirable bright red color for greater consumer appeal [91]. However, it can negatively impact the oxidative stability of protein and lipid, which is more predominant in minced pork compared to steaks [92]. 
Table 2. Some examples of non-thermal technologies utilized for muscle food processing.

\begin{tabular}{|c|c|c|c|c|}
\hline Technology & Objective & Muscle Food Product & Main Findings & Reference \\
\hline \multirow{4}{*}{$\begin{array}{l}\text { High pressure } \\
\text { processing }\end{array}$} & \multirow{3}{*}{ Microbial inactivation } & A. Chicken fillets & $\begin{array}{l}\text { A. HPP }(500 \mathrm{MPa} / 10 \mathrm{~min}) \text { may enhance the safety } \\
\text { and increase the shelf life ( } 6 \text { days at } 4{ }^{\circ} \mathrm{C} \text { and } 2 \\
\left.\text { days at } 12{ }^{\circ} \mathrm{C}\right)\end{array}$ & A. [93] \\
\hline & & B. Salmon, cod, and mackerel fillets & $\begin{array}{l}\text { B. Pressurizing at } 500 \mathrm{MPa} \text { can extend shelf life; } \\
\text { however, might have a negative effect on } \\
\text { quality parameters }\end{array}$ & B. [94] \\
\hline & & C. Rehydrated salted cod & $\begin{array}{l}\text { C. HPP }(600 \mathrm{MPa} / 5 \mathrm{~min}) \text { of rehydrated fish } \\
\text { prolonged the shelf life by at least } 49 \text { days }\end{array}$ & C. [95] \\
\hline & $\begin{array}{l}\text { Structural modifications } \\
\text { and improved functional } \\
\text { properties }\end{array}$ & A. Chicken breast myofibrillar protein & $\begin{array}{l}\text { A. Moderate HHP ( } 200 \mathrm{MPa}) \text { improved MP } \\
\text { solubility, gel hardness, WHC, and microstructures } \\
\text { of thermal MP gel; stronger HHP treatment }(\geq 300 \\
\text { MPa) weakened hardness while sharply } \\
\text { decreasing WHC }\end{array}$ & A. [96] \\
\hline \multirow{6}{*}{ Ultrasound } & \multirow{2}{*}{ Microbial reduction } & A. Salmon, mackerel, and cod fillets & $\begin{array}{l}\text { A. Ultrasound treatment for up to } 45 \mathrm{~min} \\
\text { significantly reduced the natural microflora of } \\
\text { salmon and mackerel }\end{array}$ & A. [97] \\
\hline & & B. Chicken carcasses & $\begin{array}{l}\text { B. Ultrasound bath }(1200 \mathrm{~W} / 130 \mathrm{~Hz} / 15 \mathrm{~min}) \\
\text { reduced the Campylobacter count from } 0.94 \text { to } 1.19 \\
\text { log10MPN (most probable number)/10 g }\end{array}$ & B. [98] \\
\hline & \multirow{2}{*}{$\begin{array}{l}\text { Physicochemical quality } \\
\text { improvement }\end{array}$} & $\begin{array}{l}\text { A. Restructured cooked ham with } \\
\text { reduced salt }\end{array}$ & $\begin{array}{l}\text { A. Ultrasound }\left(600 \mathrm{~W} \mathrm{~cm}^{-2} / 10 \mathrm{~min}\right) \text { showed good } \\
\text { potential for production of low salt product by } \\
\text { decreasing the total fluid release, increasing the } \\
\text { hardness, and improving color, and sensory } \\
\text { acceptance }\end{array}$ & A. [85] \\
\hline & & B. Meat emulsion & $\begin{array}{l}\text { B. Ultrasound }(25 \mathrm{KHz} / 18 \mathrm{~min}) \text { improved the } \\
\text { technological and reduced most of the sensory } \\
\text { defects caused by the reduction of } 50 \% \text { of the } \\
\text { phosphate level }\end{array}$ & B. [86] \\
\hline & \multirow{2}{*}{$\begin{array}{l}\text { Salting, curing, and } \\
\text { marination }\end{array}$} & A. Chicken breast & $\begin{array}{l}\text { A. Ultrasound-assisted sodium bicarbonate curing } \\
\text { improved the curing rate, tenderness, and WHC }\end{array}$ & A. [99] \\
\hline & & B. Pork loins & $\begin{array}{l}\text { B. The application of ultrasound increased the salt } \\
\text { percentage without modifying the } \mathrm{pH} \text {, shear force, } \\
\text { or water holding capacity }\end{array}$ & B. [100] \\
\hline
\end{tabular}


Table 2. Cont

\begin{tabular}{|c|c|c|c|c|}
\hline Technology & Objective & Muscle Food Product & Main Findings & Reference \\
\hline \multirow{3}{*}{$\begin{array}{l}\text { Cold } \\
\text { atmospheric } \\
\text { plasma }\end{array}$} & \multirow[b]{2}{*}{$\begin{array}{l}\text { Microbial } \\
\text { decontamination }\end{array}$} & A. Beef jerky & $\begin{array}{l}\text { A. A 2-3 Log CFU/g reduction in Escherichia coli, } \\
\text { Listeria monocytogenes, Salmonella Typhimurium, } \\
\text { Aspergillus flavus populations after flexible } \\
\text { thin-layer plasma treatment for } 10 \mathrm{~min}\end{array}$ & A. [101] \\
\hline & & B. Herring fillets & $\begin{array}{l}\text { B. The microbial load (total aerobic mesophilic, } \\
\text { total aerobic psychrotrophics, Pseudomonas, lactic } \\
\text { acid bacteria and Enterobacteriaceae) were lower in } \\
\text { the in-package treated samples compared } \\
\text { the control }\end{array}$ & B. [102] \\
\hline & Curing & Ground ham & $\begin{array}{l}\text { The remote infusion of CAP into meat batter } \\
\text { rapidly generated nitrite and resulted in no } \\
\text { difference in curing properties when compared } \\
\text { with sodium nitrite }\end{array}$ & [103] \\
\hline \multirow{2}{*}{$\begin{array}{l}\text { Pulsed electric } \\
\text { field }\end{array}$} & Tenderization & Beef briskets & $\begin{array}{l}\text { PEF can be used to reduce the cooking time of } \\
\text { tough meat cuts since it physically weakens the } \\
\text { connective tissue and increase the } \\
\text { collagen solubility }\end{array}$ & [104] \\
\hline & Extraction & Mussels & $\begin{array}{l}\text { PEF accelerated the extraction speed and } \\
\text { obviously improved the extraction yield of protein } \\
\text { from mussel }\end{array}$ & [105] \\
\hline
\end{tabular}




\section{Conventional and Emerging Methods of Analysis of Quality Changes in Muscle Foods}

In this section, both traditional and spectroscopic techniques used for analyzing quality changes in muscle foods will be discussed.

\subsection{Traditional Analysis Methods}

Traditional methods used to determine quality changes in muscle foods can be divided into methods to determine changes in proximate composition and methods to determine changes in specific components during processing.

Proximate composition such as content of water/dry matter, ash, and total amount of proteins and lipids can give some information on changes taking place during processing, but the information is usually limited. However, the proximate composition is usually needed as a basis for other more specific methods. For muscle foods, the water content/dry matter is usually determined by drying at $105{ }^{\circ} \mathrm{C}$ for $24 \mathrm{~h} \mathrm{[106],} \mathrm{but} \mathrm{other} \mathrm{methods} \mathrm{such} \mathrm{as} \mathrm{drying} \mathrm{using} \mathrm{IR} \mathrm{is} \mathrm{also} \mathrm{used.} \mathrm{The} \mathrm{ash} \mathrm{content}$ which reflects the minerals content is determined by combustion in an ashing/combustion oven at $550{ }^{\circ} \mathrm{C}$ overnight [107]. For determination of lipid content several methods exist. These are the Bligh and Dyer method [108] and the Folch method [109], which both rely on extracting the lipids in a mixture of chloroform/methanol and water. The Soxhlet method uses different solvents as extraction medium - usual solvents are hexane or mixtures of hexane and acetone or hexane and dichloromethane [110].

The microbial load is also an important quality parameter that is used both to determine shelf life and the effect of different processing and storage parameters such as the effect of heating, superchilling, and MAP packaging $[111,112]$. The microbial load is measured as total viable count (TVC) but this cannot be used alone as an indicator of spoilage. To determine spoilage, the count of psychrotrophic bacteria or sulfide reducing bacteria as well as number of specific spoilage bacteria are commonly used [111].

Changes during processing can be measured by determination of changes in different properties of proteins and lipids. To measure changes taking place in proteins and lipids, a wide range of different methods are used. One of the simplest methods to measure changes in proteins is to measure changes in solubility. Muscle proteins can be divided into three groups based on solubility-water soluble (sarcoplasmic), salt soluble (myofibrillar), and insoluble (connective tissue) proteins. The myofibrillar proteins are susceptible to denaturation during processing and changes in the solubility or extractability of these can reflect changes during processing. This has been used to study changes during storage (ice, frozen storage) as well as heat treatment [106,113]. Iced and superchilled storage as well as freezing and thawing may also lead to leakage of enzymes from lysosomes. This has been used to detect changes during superchilled, iced storage, as well as to detect if product or sample has been frozen [114]. During processing and storage, muscle proteins may be degraded, and this is reflected in changes in molecular weight. This can be measured by an increase in acid soluble peptides and free amino acids. The proteins can also be denatured-and the denaturation can be determined by measuring changes in solubility properties as discussed above. It is also possible to analyze which proteins are changed by electrophoresis or chromatography [113,115].

Changes in lipids are usually determined by determining degree of lipid oxidation. This is measured as a combination of primary and secondary oxidation products. The commonly used primary oxidation product is peroxide value (PV) usually measured by iodometric titration [116] but also spectrophotometric methods are used [117]. Content of conjugated dienes and trienes are also used as measured of primary oxidation products. For secondary oxidation products, determination of content of thiobarbituric acid reactive substances (TBARS) is commonly used in addition to determination anisidine value. The fatty acid composition and other related compounds can also be used to determine changes in lipids during storage and processing but is usually not sensitive enough to detect small changes $[4,118]$. 
Changes in functional properties such as drip loss, changes in water holding capacity/water binding, cook loss, texture, and gelling properties are also used to determine changes in fish during storage and processing $[119,120]$. The methods used to determine functional properties are usually not standardized and are highly lab dependent making comparison of results from different laboratories difficult. Texture can be determined instrumentally using a texture analyzer [121]. Several methods are used to determine water holding capacity-including methods using pressure and low speed centrifugation methods [122]. Processing often results in changes in color and this can be determined by color meters which record the color coordinates, namely $L^{*}$ (lightness, black $=0$, white $=100$ ), $a^{*}$ (redness $>0$, greenness $<0$ ), and $b^{*}$ (yellowness, $b^{*}>0$, blue $<0$ ) according to the Commission Internationale de l'Éclairage (CIE) LAB color scale [123].

Sensory analysis is the measure of quality of food using human senses. Different methods are used depending on the purpose of the analysis, whether different processing parameters lead to differences in the products or there is a need to analyze what quality parameters are affected. For analyzing quality changes during processing, a descriptive sensory analysis can be used [124,125]. Other well-established sensory assessment methods such as quality index method (QIM), have been widely applied [126,127].

\subsection{Brief Overview of Spectroscopic Techniques}

Qualitative and quantitative applications of vibrational spectroscopic techniques are well established in the food industry [128-140]. Vibrational spectroscopy (infrared; IR, Raman) has been one of the most attractive and commonly used methods of analysis as it allows for simultaneous, rapid, and non-destructive determination of major components in many agriculture-related products and plant materials [128-140]. Mid (MIR), near infrared (NIR), and Raman spectroscopy are classified as molecular/vibrational spectroscopy techniques and they are used to evaluate and study the interactions of electromagnetic waves with a sample. The electromagnetic spectrum comprises different types of radiation, ranging from radio waves (lower end of the spectrum) through to gamma rays (upper end) [128-140]. Molecules absorb IR owing to the vibrational movements of their chemical bonds (e.g., bending, stretching, rocking, wagging, or scissoring). As these actions occur solely at specific energy levels, chemical bonds absorb IR radiation of defined energies at distinct wavenumbers or wavelengths. Infrared spectroscopy is the measure of this absorption, resulting in a spectrum with peaks representing the chemical bonds present in the given sample [128-140].

The NIR region of the spectrum is located between 700 and $2500 \mathrm{~nm}$. NIR spectroscopy has been established as an efficient analytical technique in the food industry when combined with chemometric tools (e.g., data mining and data processing). As the absorption bands in the NIR region are weaker than those in the MIR (between 10 and 100 times) the NIR energy facilitates that samples can be analyzed directly without the need of preprocessing (e.g., drying, homogenization, grinding). Overall, the NIR spectra is the result of overtone and combination bands of fundamental vibrations of $\mathrm{C}-\mathrm{H}, \mathrm{O}-\mathrm{H}$, and N-H bonds [128-140]. The interpretation of NIR spectra can be hindered further as consequence of not only the many overlapping bands but also because an individual analyte might absorb at several wavelengths. The MIR region ( $\left(4000-400 \mathrm{~cm}^{-1}\right)$ has been very important in the development of several applications in different fields (e.g., biology, environment, and food) [128-140].

The MIR is of particular importance analytically as it contains the so called biochemical and chemical fingerprint region $\left(1500-400 \mathrm{~cm}^{-1}\right)$. The MIR region is known to contain a number of common biochemical and chemical compounds that are present in complex food matrices such as Amide I, II, and III around 1650, 1550, and $1260 \mathrm{~cm}^{-1}$, carbohydrates around $1155 \mathrm{~cm}^{-1}$, glycogen around $1030 \mathrm{~cm}^{-1}$, lipids and ester groups around $1750 \mathrm{~cm}^{-1}$, asymmetric phosphate stretching vibrations $\left(\mathrm{PO}_{2}^{-}\right)$around $1225 \mathrm{~cm}^{-1}$, symmetric phosphate stretching vibrations $\left(\mathrm{PO}_{2}^{-} ; \approx 1080 \mathrm{~cm}^{-1}\right)$, and protein phosphorylation around $970 \mathrm{~cm}^{-1}$ [128-140]. The MIR range between 1500 and $400 \mathrm{~cm}^{-1}$ is also known as the fingerprint region. Absorption values or peaks in the fingerprint region are predominantly produced by bending and skeletal vibrations, which are sensitive to large wavenumber shifts, minimizing against unambiguous identification of specific functional groups. Analysis of 
such fingerprints is the basis of many applications of MIR spectroscopy in food analysis [128-140]. The incorporation of attenuated total reflectance (ATR) has boosted the use of MIR spectroscopy in food analysis, allowing for the development of new applications as it removes any necessity for sample preparation, as the ATR accessory extends the path length assessed by the instrument significantly. Spectra originated in the MIR region are characterized by intense and more selective bands or peaks associated with molecules present in the food matrix (fundamental frequencies) [128-140].

Raman spectroscopy, based on the inelastic scattering of monochromatic light when interacting with molecules, is gaining an increasingly wider area of applications in different industries (e.g., pharmaceutical, food) [141-143]. Raman spectroscopy provides rich information of the molecule's vibrational modes, as well as its characteristic structure [141-143]. Although only a small fraction of the incident light is inelastically scattered, resulting in the Raman scattering being a naturally weak effect, the weak counterpart of the incident light energy is modified by the molecular vibrations of the scattering sample [141-143]. Therefore, the observed vibrational responses provide the analyst with enough information about the chemical composition of the sample [141-143]. In recent years, measuring the Raman spectra of complex samples (e.g., muscles, cereals, wine) in situ has been more accessible due to the release of high resolution and portable instruments that provide good detection capabilities [141-143]. Indeed, several kinds of handheld and portable Raman and NIR spectrometers have been developed in the recent years for on-site food quality applications in real time. Although some loss of information can occur, this can be compensated by the reduction of measurement time and instrumentation costs, as well as low power consumption, user-friendliness, and tailored design $[132,144,145]$. For example, spatially offset Raman (SORS) can be used to obtain layered subsurface information by collecting Raman scattering signals from a series of surface positions. Increasing the distance (offset) between the laser and detector results in less signal contributions from the surface and more Raman signatures from the subsurface layers $[143,146]$.

Most of the applications based in vibrational spectroscopy reported in the literature have been primarily target on spot measurements using either the NIR or visible (Vis) regions of the electromagnetic spectrum. More recently, a diverse range of hyperspectral devices, including cameras and spectral imaging devices, are now readily available providing exciting new possibilities in food analysis and processing. This technology can acquire either single or multiple images at discrete wavelengths, presenting the potential for the detection of specific attributes relating to quality in an extensive range of raw materials and products $[41,147,148]$. Overall, the availability of hyperspectral imaging (HSI) and multispectral imaging (MSI) systems allowed for obtaining spatial, spectral, and multiconstituent information about the sample being analyzed has increased notably [41,147,148].

Multispectral imaging involves the acquisition of spectral images at few discrete and narrow wavebands (bandwidths of between 5 and $50 \mathrm{~nm}$ ) and it might be considered an improvement of HSI as this technology is cost effective $[41,147,148]$. The result is the ability of MSI to simultaneously predict multiple components, providing a key advantage and rendering a promising future outlook with a single, automated image acquisition $[41,147,148]$. HSI relies on one of two sensing modes as in-line scanning (push broom) mode (Figure 2) or as filter-based imaging mode $[41,147,148]$. In-line scanning mode involves the imaging system scans moving product items. This results in three-dimensional (3D) hyperspectral images, also called hypercubes [41,147,148]. In filter-based imaging mode, spectral images are obtained from stationary targets for a waveband sequence using either a liquid crystal tuneable filter or an acousto-optical tunable filter $[41,147,148]$. In-line scanning is the most common as it is relatively easy to implement, particularly for real-time and online applications. In comparison, filter-based HSI systems are not suitable for online applications and they require a different approach in analysis of the data $[41,147,148]$. 

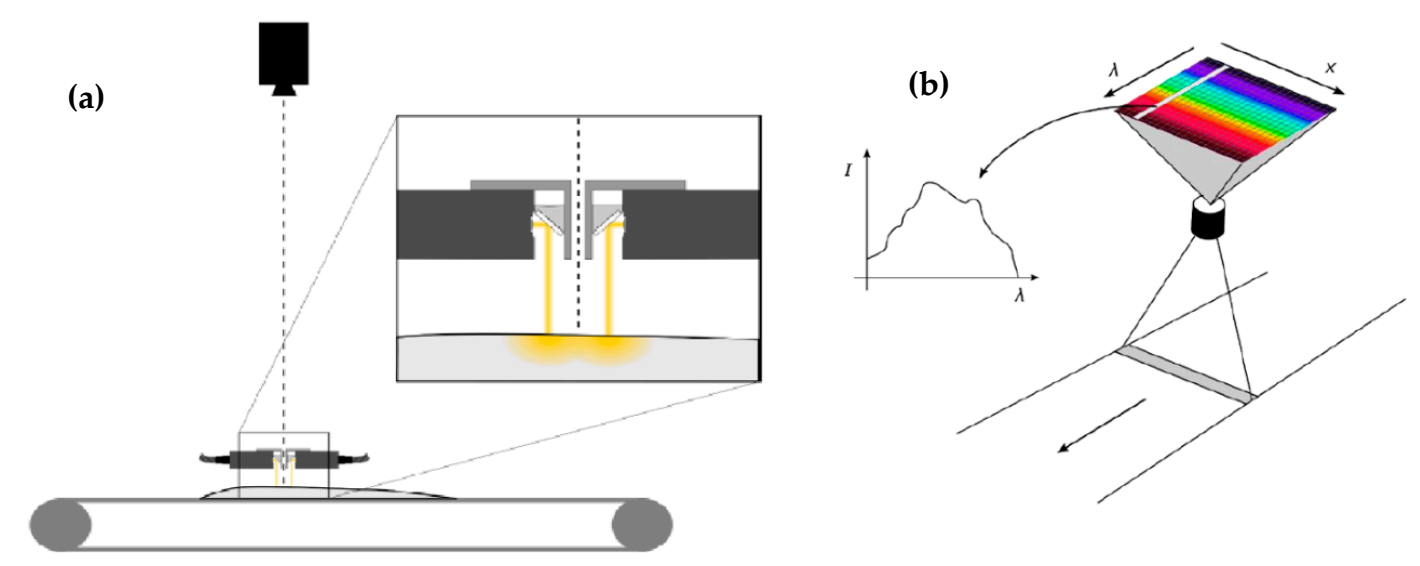

Figure 2. Hyperspectral imaging used for interactance mode. Hyperspectral camera, conveyor belt and fiberoptic line lights used for interactance mode imaging (a), and concept of hyperspectral camera, image one spatial line at time with full spectral information (b). Adapted from Nofima's report 28/2017: Automatic quality control of internal defects in cod-results from hyperspectral, ultrasound, and X-ray imaging.

HSI methods require a high-performance digital camera that has the ability to cover the spectral region of interest, in a wide dynamic range with high signal-to-noise-ratio, and good quantum efficiency $[41,147,148]$. An imaging spectrograph, with the ability to disperse the line images into different wavelengths is essential. Optical resolution and spectral response efficiency with minimal aberrations are also key features of a HSI system. HSI is particularly attractive for food applications because of the integration of imaging ability with spectroscopy, which enables the simultaneous acquisition of both spectral and spatial information from the target. The gains achieved by this amalgamation can allow for the monitoring of highly spatially variable raw and food products $[41,147,148]$. However, this technology is not widely used by the food industry, with key considerations to user uptake depending on several reasons that include cost and instrument availability, whether the application is online or in-field and training of staff $[41,147,148]$.

In addition to the aforementioned vibrational spectroscopic methods, the potential of other spectroscopic techniques, such as fluorescence spectroscopy, nuclear magnetic resonance (NMR), and electron spin resonance (ESR) has been widely explored in several thermal and non-thermal treatment applications $[33,149,150]$.

It should be underlined that there is no perfect analytical technique and every spectroscopic method has pros and cons as it is shown in Table 3. For example, although the fluorescence spectroscopy is characterized by its high sensitivity and selectivity, the technique is mainly limited to sample surface inspection and can be highly affected by the well-known inner filter effect. Other spectroscopic techniques are more suitable to collect information from inside the sample, such as NIR spectroscopy, especially when it is used in the interactance mode, while SORS technique allows to collect signals from different layers of the sample.

As will be seen in the following section, most thermal and non-thermal treatments will affect the optical properties, especially scattering, and consequently the absorption of the sample. This effect should be taken into consideration when interpreting the obtained results, particularly those of fluorescence spectroscopy. Indeed, depending on the optical geometry of the fluorescence measurements (i.e., right angle, front-face), the spectral pattern and fluorescence intensity will be strongly affected by the amount of the absorbed and scattered light. This means that not only the chemical changes and fluorophore concentrations are of a determinant importance but also scattering and absorption properties are important factors that impact the results. It is well-known that the scattering is associated with the structural and physical properties of the sample, while the absorption is mainly related to the chemical composition and concentration of the various chemical components that absorb light at different wavelengths in different manners. 
Table 3. The pros and cons and other characteristics of the main spectroscopic techniques. The table is adopted from [131,151].

\begin{tabular}{|c|c|c|c|c|}
\hline $\begin{array}{l}\text { Spectroscopic } \\
\text { Technique }\end{array}$ & $\begin{array}{l}\text { Wavelength } \\
\text { Limits }\end{array}$ & Type of Transition & Advantages & Limitations \\
\hline Fluorescence & $250-750 \mathrm{~nm}$ & $\begin{array}{l}\text { Bonding electrons } \\
\text { in molecules }\end{array}$ & $\begin{array}{c}\text { Rapid, high accuracy, } \\
\text { sensitivity, relatively low cost }\end{array}$ & $\begin{array}{l}\text { Limited to samples containing } \\
\text { fluorophores, sample surface } \\
\text { technique, inner filter effect }\end{array}$ \\
\hline Near-infrared & $750-2500 \mathrm{~nm}$ & $\begin{array}{l}\text { Overtones and } \\
\text { combinations of } \\
\text { fundamental bands }\end{array}$ & $\begin{array}{l}\text { Less sample preparation } \\
\text { requirement, high sensitivity } \\
\text { to physical structure and } \\
\text { presence of water }\end{array}$ & $\begin{array}{l}\text { Requires reliable reference } \\
\text { methods, low specificity, } \\
\text { overlapped and complex spectra }\end{array}$ \\
\hline $\begin{array}{l}\text { Hyperspectral } \\
\text { imaging }\end{array}$ & $\begin{array}{c}400-1000 \mathrm{~nm} \\
\text { (most common) }\end{array}$ & - & $\begin{array}{l}\text { Providing spatial information } \\
\quad \text { (pixel-to-pixel signal) }\end{array}$ & $\begin{array}{l}\text { Huge amount of data and data } \\
\text { processing, costs }\end{array}$ \\
\hline Mid-infrared & $2500-25,000 \mathrm{~nm}$ & $\begin{array}{l}\text { Fundamental } \\
\text { stretching, bending, } \\
\text { and rotating }\end{array}$ & $\begin{array}{l}\text { High sensitivity to chemical } \\
\text { compositions, distinct } \\
\text { absorption peaks }\end{array}$ & $\begin{array}{l}\text { Water interference; limited } \\
\text { suitability of moist samples. } \\
\text { Low light penetration }\end{array}$ \\
\hline Raman & $\begin{array}{c}750-1064 \mathrm{~nm} \\
(\text { excitation) } \\
2500-200,000 \mathrm{~nm}\end{array}$ & $\begin{array}{l}\text { Vibrational } \\
\text { transitions }\end{array}$ & $\begin{array}{l}\text { Provides structural and } \\
\text { qualitative information, low } \\
\text { sensitivity to water }\end{array}$ & $\begin{array}{l}\text { Interference from biological } \\
\text { fluorescence background } \\
\text { signals, small part of the sample } \\
\text { is irradiated (laser spot), low } \\
\text { sensitivity, and complex } \\
\text { instrumentation }\end{array}$ \\
\hline $\begin{array}{l}\text { Nuclear } \\
\text { magnetic } \\
\text { resonance }\end{array}$ & $1-1000 \mathrm{~m}$ & $\begin{array}{l}\text { Nuclei orientation } \\
\text { into a magnetic } \\
\text { field }\end{array}$ & $\begin{array}{l}\text { Accuracy, determination of } \\
\text { precise structures, minimal } \\
\text { sample preparation, spatial } \\
\text { information (magnetic } \\
\text { resonance imaging: MRI) }\end{array}$ & $\begin{array}{l}\text { Expensive equipment, low } \\
\text { sensitivity, overlapping signal, } \\
\text { especially when analyzing } \\
\text { complex mixtures }\end{array}$ \\
\hline
\end{tabular}

The following section will present relevant examples about the use of different spectroscopic techniques for monitoring thermal and non-thermal treatments in fish and meat. It should be stressed that, for the sake of simplicity, the bands and their assignments will not be presented here, since other relevant reviews are already available in the literature. For example, for more information about Raman and IR spectral features and the major vibrational features and their corresponding assignments, the reader is referred to the following review papers [131,152].

\section{Use of Spectroscopic Techniques for Monitoring Changes in Muscle Foods during Processing}

\subsection{Fish and Other Seafoods}

This section will give examples on the application of spectroscopic techniques for monitoring changes in fish and other seafoods following the use of thermal and non-thermal treatments.

\subsubsection{Thermal Treatments}

Evaluation and understanding of quality changes induced in fish and other seafoods during the application of thermal treatments are necessary in order to better monitor and optimize the heating process $[32,153,154]$. In addition to the reference and official methods used for evaluating heat treatments (discussed in Section 3.1 of this review), many studies have investigated the potential of several spectroscopic techniques, such as Raman, infrared-based techniques, fluorescence, and NMR. Practical examples of these techniques will be given in this section.

Raman Spectroscopy: This technique can give structural information about proteins, lipids, and water of muscle foods during processing or storage [155]. Raman spectroscopy is especially useful when studying changes in secondary structure of proteins. For instance, several studies have been conducted using Raman spectroscopy to investigate changes occurring in the secondary structure of surimi protein during the application of different thermal treatments [156-158]. More specifically, Raman spectra can provide useful information about changes taking place in $\alpha$-helix and $\beta$-sheet structures of protein as affected by thermal treatments. Indeed, it has been frequently reported 
that the content of $\alpha$-helix decreases, while the content of $\beta$-sheet increases with increasing temperature $[54,154,157]$.

Visible and Infrared-Based Techniques: Visible (Vis), NIR, and MIR are more frequently applied techniques for monitoring thermal treatments in fish and other seafood.

Vis-NIR spectroscopy has been tested in several studies for assessing endpoint and surface temperatures in fish and other seafood [159-161]. Two similar studies reported that the spectral range between 400 and $550 \mathrm{~nm}$ was especially relevant for predicting thermal loads in heat-treated surimi $[160,162]$. In these studies, the authors observed a decrease in absorption with increasing cooking time and temperature, which was attributed to increased scattering caused by protein denaturation. The authors concluded that the technique can be used as a rapid tool for monitoring thermal treatments during the processing of seafood.

Formerly, Uddin and collaborators conducted several valuable studies to investigate the potential of NIR spectroscopy for monitoring thermal treatments in several seafood products $[159,161,163]$. Although these studies were conducted at laboratory scales, the obtained results were promising and paved the way for further investigations in this context.

In recent years, HSI has matured to become one of the most powerful tools used for quality and control in the food industry. This technique has been frequently used within several spectral ranges, especially NIR, giving spatial information in addition to the spectral features that are usually obtained with traditional spectroscopic techniques. One example is the study conducted by ElMasry and Nakauchi [164], who used HSI operating in the 900-2500 nm spectral range in order to classify kamaboko, a Japanese seafood, receiving different thermal treatments. The authors applied a partial least square regression (PLSR) model to estimate core temperature and thermal history and linear discriminant analysis (LDA) model to classify samples according to their thermal treatments. Both models achieved good results since $\mathrm{R}^{2}{ }_{\mathrm{P}}$ of 0.86 and 0.83 were obtained for predicting core temperature and thermal history, respectively. The LDA model yielded an overall classification accuracy of $93.75 \%$ in both calibration and validation sets. More interestingly, the optimal models were applied to the images in a pixel-wise manner in order to produce prediction and classification maps, visualizing weather the processed product has reached certain thermal conditions just by looking at the color of the generated images. In a more recent study, the performance of two different instruments based on NIR (760-1040 nm), namely a point measurement system and a commercial on-line NIR imaging scanner (QMonitor, TOMRA, Norway), operating in an interactance mode for determining the core temperature of heat-treated fish cakes, was compared [153]. Although slightly better results were obtained using the offline point measurement system, as a result of deeper penetration of light into the sample, the on-line imaging scanner was highlighted due to its potential to be adapted for a typical conveyor belt, giving the opportunity to monitor the temperature in all products after heat treatment in the industrial application.

Fourier transform infrared (FT-IR) spectroscopy is a biochemical fingerprinting technique that has attracted much attention in recent years due to many desirable features such as high speed, resolution, and sensitivity [158]. Like Raman spectroscopy, FT-IR has been widely used to study changes in the secondary structure of proteins as induced by thermal treatments.

Again, the changes of the secondary structures of surimi gels have been studied by FT-IR in order to improve the texture and solve the problem of decreased gel strength of surimi when applying high temperatures to treat the product [158]. The results of FT-IR, along with those of Raman spectroscopy showed that the network structure of the gel surimi undergoes serious damages when treating the surimi at high temperatures (i.e., 100 and $120^{\circ} \mathrm{C}$ ). As protein denaturation and aggregation have the main responsibility for physical modifications and other related changes (e.g., cooking loss, changes in water holding capacity) occurring in seafood during thermal processing, FT-IR has been widely used to study these phenomena $[157,158,165,166]$. For example, Ovissipour and coauthors found that the changes in the amide I band $\left(1700-1600 \mathrm{~cm}^{-1}\right)$ are the most useful for studying denaturation in alteration in the secondary structure of protein upon heating [165]. In more detail, it was found that the peak intensity of 
the band located around $1652 \mathrm{~cm}^{-1}$, related to the $\alpha$-helical structures, increases with increasing heating temperatures, whereas an inverse behavior was observed for $\beta$-sheet structures (around $1618 \mathrm{~cm}^{-1}$ ), in agreement with the previously reviewed results obtained by Raman spectroscopy.

Fluorescence Spectroscopy: The use of fluorescence spectroscopy for monitoring thermal treatments has been widely reported on several food products [167-171], while limited research has been carried out on fish and other seafood. Moreover, in most of these studies, fluorescence spectroscopy was used as a supplementary technique that confirmed the results obtained by using other measurement techniques $[49,172,173]$.

One of the chemical changes that occur in muscle foods during cooking or other thermal processing treatments is the formation of Schiff bases. These compounds result from the crosslinking reaction between amino groups of proteins and aldehydes from lipid oxidation, and can be measured by fluorescence spectroscopy [49,172]. In a study conducted by Hu and al. [49], a much higher impact of roasting and frying of sturgeon (Acipenser gueldenstaedtii) on fluorescence intensity was observed than that of billing or steaming. In addition, depending on cooking methods, different shifts in the maximum emission wavelength were observed, suggesting the accumulation of Schiff bases with various chemical structures. In a similar study, the length of the roasting time of the same fish species was found to exert a significant effect on the fluorescence spectra and, consequently, on the formation of Schiff bases [172].

Other studies investigated the impact of different cooking methods on the formation of Maillard reaction products, as assessed by fluorescence spectroscopy. For example, the formation of these products was measured in hairtail (Thichiurus lepturus) fillets prepared by three cooking methods, namely boiling, baking, and frying. Higher fluorescence levels were observed in the baked and fried fillets compared to that in the boiled ones. One of the main conclusions of this study was that the measurement of fluorescent compounds can be used to evaluate the progress of Maillard reaction in cooked foods.

In addition to the use of fluorescence spectroscopy for studying Schiff bases and Maillard reaction products, in other studies, good correlations were found between fluorescence data and traditional physico-chemical measurements. Recently, measurements based on fluorescence spectroscopy and microscopy resulted in interesting findings regarding the assessment of changes in some quality parameters (e.g., changes in fish texture, formation of oxidation products) occurring in fish during the application of different thermal treatments [174-176].

It is well-known that fluorescence from proteins is due to emission from the aromatic amino acids, especially tryptophan. Decreases in fluorescence intensity and red shift of the maximum emission are reported in several studies in the literature to be the result of thermal protein denaturation and tryptophan exposure to increasing solvent polarity $[54,177]$. Thus, the fluorescence properties of tryptophan have been used to provide information about the extent of thermal treatments and protein denaturation occurring during various processing. For example, it was found that the degree of fluorescence intensity in surimi gel was dependent on the duration of microwave heating [177].

Another interesting field of application of fluorescence spectroscopy, as other spectroscopic techniques, is the possibility to exploit the spectra for classification purposes, with the basic underlying idea that the spectrum for a specific sample exhibit specific features compared to the spectrum of other samples [178]. In this context, our recent results showed that the fluorescence data were able to classify cod fillets subjected to different cooking temperatures [176]. Indeed, the results of fluorescence spectroscopy coupled with multivariate analysis, especially support vector machine, allowed to classify cod fillets, thermally treated in a water bath at 50,60,70, and $80^{\circ} \mathrm{C}$, according to the their received thermal treatments, with an accuracy higher than $92 \%$ being obtained.

Most of the aforementioned studies were conducted using traditional excitation/emission procedure. Although this approach can be rapid and give valuable information if the fluorophore to be investigated is well-known, it can limit the potential of fluorescence spectroscopy for investigating several fluorophores simultaneously. Fluorescence excitation-emission matrices (EEM), or called 
fluorescence landscapes in some references, take longer time to collect but enable scanning over a wide range of excitation and emission wavelengths, giving more information about fluorophores present in the sample. The EEM technique was investigated recently to identify changes of fluorescence behavior of shrimp during different treatments, including ohmic heating [54]. One of the spectroscopic results reported in this study was that the tryptophan fluorescence appeared to be highly dependent on the temperature of the treated shrimp samples.

Nuclear Magnetic Resonance (NMR) Spectroscopy: NMR is an important tool for the investigation of the effects of thermal treatments on quality changes of seafood. Low-field nuclear magnetic resonance (LF-NMR) and magnetic resonance imaging (MRI) have been widely used for studying water migration, water mobility changes, and water distribution during food processing [150]. NMR chemical shift and $T_{2}$ relaxation behaviors are among the widely NMR used parameters for evaluating the state on moisture in the measured samples, and consequently, monitoring structural changes occurring in seafood during cooking or other thermal treatments. For example, $T_{2}$ parameters were found to be correlated with texture profile analysis (TPA) parameters of sea cucumber (Stichopus japonicus) during a two-step heating; pre-heating and post-heating [179]. In another study, NMR and MRI were used to investigate the impact of three cooking methods (frying, boiling, and stewing) of turbot on water mobility and distribution and the relationship with traditional parameters, including texture and color [180]. PCA applied to the NMR data showed a clear discrimination between the samples according to their cooking method, while weighted images of the MRI scans provided visualizations of internal structural information. In a recent study, low-field nuclear magnetic resonance (LF-NMR) and magnetic resonance imaging (MRI) techniques were used to study the impact of four cooking methods, including boiling, steaming, roasting, and frying on proton dynamics, physicochemical parameters, and microstructure of Spanish mackerel [181]. $T_{1}$ weighted magnetic resonance images were recorded and a significant decrease of MRI intensity for mackerel samples after roasting and frying was observed, demonstrating that these cooking methods were more drastic in changing the proton states than boiling and steaming. PLSR models applied to LF-NMR data to predict texture parameters (hardness, resilience, springiness, chewiness, gumminess, and adhesiveness) showed good reliability and accuracy with correlation coefficients of more than 0.98 being obtained. The same technique was used recently to monitor water dynamic changes in surf clam during heating [182]. The results of principle component analysis (PCA) and heatmap showed that the clam samples heated at $40-70{ }^{\circ} \mathrm{C}$ were different from those treated at high temperatures $\left(80-100{ }^{\circ} \mathrm{C}\right)$.

\subsubsection{Non-Thermal Treatments}

The determination of the freshness and quality of packaged food is problematic since direct contact with food is not visible and use of the sample in destructive way carries a significant cost. This issue is commonly encountered with products treated with emerging technologies, such as irradiation and HPP that aim at treating packaged products. Non-destructive spectroscopy techniques enable the examination of freshness and determination of the quality of packaged muscle foods. Thus, enable making proper decisions regarding their shelf life without compromising the product's integrity.

Raman Spectroscopy: Little has been reported on the use of Raman spectroscopy for monitoring changes in fish and other seafoods following non-thermal treatments. One of the scarce examples available in the literature is the study conducted by Tintchev and others who applied resonance Raman spectroscopic to investigate smoked salmon meat after HPP (up to $600 \mathrm{MPa}$ ) [183]. The technique provided novel insights to understand structural changes occurring in astaxanthin and myoglobin (the key components of smoked salmon flesh) as well as the degradation mechanisms of the carotenoid, which is the origin of the color attenuation of smoked salmon after the pressure-treatment.

Fourier-Transform Infrared (FT-IR) Spectroscopy: The technique was found to be useful to monitor changes in lipid oxidation (formation and decomposition of free fatty acids and hydroperoxides) in muscle foods. For example, FT-IR spectra contain bands showing vibration of the C-O group 
and bending vibration of the $\mathrm{CH}_{2}$ groups at wavelength of 1162.79 and $1215.70 \mathrm{~cm}^{-1}$, respectively, are associated with saturated acyl groups, cis $\mathrm{C}=\mathrm{C}$ at $1657.16 \mathrm{~cm}^{-1}$ that is assigned to unsaturated acyl groups, a stretching vibrational band for the $\mathrm{C}=\mathrm{O}$ carboxylic group at wavelength of $1739.29 \mathrm{~cm}^{-1}$ that represent free fatty acids, and a band at wavelength of $3341.52 \mathrm{~cm}^{-1}$ representing hydroperoxides. The detection of formed FFA and hydroperoxides in striped catfish oil samples demonstrated the synergistic effect of modified atmospheric packaging (MAP, $60 \% \mathrm{~N}_{2} / 35 \% \mathrm{CO}_{2} / 5 \% \mathrm{O}_{2}$ ) and tannic acid addition to control lipid oxidation in chilled striped catfish [117].

FT-IR wavelengths in regions from 1752 to $1735 \mathrm{~cm}^{-1}$, from 1560 to $1245 \mathrm{~cm}^{-1}$, and from 1160 to $1025 \mathrm{~cm}^{-1}$ were used in a PLSR model to predicate freshness, TVC, and some specific microorganisms in fresh salmon stored under various packaging systems (aerobic, MAP $\left(50 \% \mathrm{~N}_{2} / 40 \% \mathrm{CO}_{2} / 10 \% \mathrm{O}_{2}\right)$ ) at 3, 8, and $30{ }^{\circ} \mathrm{C}$ [184]. The TVC and psychrotrophs, lactic acid bacteria, molds, and yeasts, Brochothrix thermosphacta, Enterobacteriaceae, Pseudomonas spp., and $\mathrm{H}_{2} \mathrm{~S}$ producing bacterial counts were successfully with $R^{2}$ in the range of $0.61-0.87$.

The technique was proven to be very useful in investigating the effect of HPP treatment on the protein structure [185]. The $\mathrm{C}=\mathrm{O}$ stretching vibration representing the amide I band in $1600-1700 \mathrm{~cm}^{-1}$ wavelength range was suggested to be a useful indicator of the secondary structure of protein. In particular, bands at 1652 and $1683 \mathrm{~cm}^{-1}$ are related to $\alpha$-helical and intramolecular antiparallel $\beta$-sheet structures, respectively, in salmon [185]. Slightly different wavelengths have been reported for shrimp where the wavelengths related to $\beta$-sheets in the amide I region were found at 1613-1637; $1682-1696 \mathrm{~cm}^{-1}$, for $\alpha$ - helices at $1645-1662 \mathrm{~cm}^{-1}$, for turns at wavelengths $1662-1682 ; 1630 \mathrm{~cm}^{-1}$ and for unordered structure at $1637-1645 \mathrm{~cm}^{-1}$ [186]. FT-IR confirmed structural changes in the secondary and tertiary structures of protein upon HPP treatment above $200 \mathrm{MPa}$. These changes were lessened in salmon treated by HPP ( $300 \mathrm{MPa}$ for $10 \mathrm{~min}$ ) at low temperature (i.e., at $5{ }^{\circ} \mathrm{C}$ compared to $40^{\circ} \mathrm{C}$ ) and the use gelatin-lignin film, which resulted in better salmon quality. Similar uses of FT-IR to examine the protein structure of blue crab meat subjected to HPP treatment [125,187], palm ruff treated by HPP [188], and shrimp treated by ultrasound processing [186] have been reported. These studies confirmed that HPP treatment $\left(100,300\right.$, and $600 \mathrm{MPa}$ for $5 \mathrm{~min}$ at $\left.10^{\circ} \mathrm{C}\right)$ and ultrasound processing (20-kHz frequency, $400 \mathrm{~W}$ for various times at room temperature) resulted in a lower percentage of $\alpha$-helix and a higher percentage of $\beta$-turn secondary structures compared to untreated samples. Collectively, the above results confirmed the ability of FT-IR as a fast, reliable, and accurate technique for the evaluation of freshness and quality of muscle foods.

Fluorescence Spectroscopy: The combination of fluorescence and chemometric techniques can be successfully used as a non-destructive method to evaluate the quality of foods. Hassoun and Karoui [116] evaluated the quality of whiting fillets in MAP $\left(50 \% \mathrm{~N}_{2} / 50 \% \mathrm{CO}_{2}\right.$ or $\left.80 \% \mathrm{~N}_{2} / 20 \% \mathrm{CO}_{2}\right)$ stored at $4{ }^{\circ} \mathrm{C}$ for up to 15 days using physicochemical properties and front face fluorescence spectroscopy emission spectra. A complete segregation of the treatments was achieved using PCA. Lower lipid oxidation, total volatile basic nitrogen, and better texture attributes were found in the MAP treated samples with the $50 \% \mathrm{CO}_{2}$ showing best protection during the cold storage.

Hyperspectral Imaging (HSI): Fresh salmon stored aerobically, under MAP $\left(60 \% \mathrm{CO}_{2} / 40 \% \mathrm{~N}_{2}\right)$ or $90 \%$ vacuum packaging at $4{ }^{\circ} \mathrm{C}$ was investigated using HSI [189]. Spectral differences were observed among the treatments, especially at 606 and $636 \mathrm{~nm}$ that were suggested to be related to the oxidation state of hemoproteins. Classification model was obtained (>88\%) using wavelengths at $606,636,665$, 705 , and $764 \mathrm{~nm}$. The technique was successful in classifying smoked salmon and separate expired product from saleable product at success rate of $82.7 \%$ [190].

Magnetic Resonance Techniques: LF-NMR was used to investigate the freshness and quality of half-smooth tongue sole fillets subjected to edible coating treatment and stored chilled in different packaging systems including MAP [191]. The technique provided valuable information on the moisture status from the transverse relaxation times (bound in $T_{21}$ range $1.32-6.14 \mathrm{~ms}$, immobilized in $T_{22}$ range of $28.48-117.38 \mathrm{~ms}$, and free in $T_{23}$ range of $403.7-3274.55 \mathrm{~ms}$ ) in the fillets. Significant correlations in the range $0.796-0.898$ were found for $T_{22}$ and $\mathrm{H}_{2} \mathrm{O}$ and fat contents as well as the $\mathrm{Ca}^{2+}$-ATPase 
activity in the fillets. Furthermore, significant correlations (0.802-0.966) were found for $T_{23}$ and lipid oxidation, total volatile basic nitrogen, and $\mathrm{K}$ value. The study also employed MRI technique to obtain information on the molecular distribution and internal morphological organization of the sample matrix. Overall, MRI enabled the monitoring of the microstructure of the samples and supported the use of MAP and edible coating to maintain freshness and product shelf life. The use of LF-NMR and MRI enabled the prediction of product quality and shelf life.

The ability to detect methylated amines and nucleotide degradation products using ${ }^{1} \mathrm{H}$ NMR was investigated in fresh sardines stored chilled in various packaging systems (aerobic; MAP $\left(30 \% \mathrm{CO}_{2}+70 \% \mathrm{~N}_{2} ; 30 \% \mathrm{CO}_{2}+70 \% \mathrm{~N}_{2} \mathrm{O}\right.$ and $\left.30 \% \mathrm{CO}_{2}+70 \% \mathrm{Ar}\right)$ ) [192]. The obtained ${ }^{1} \mathrm{H}$ NMR spectra were used to determine the concentrations of trimethylamine- $\mathrm{N}$, trimethylamine-O, hypoxanthine, adenosine-5'-diphosphate, adenosine-5'-monophosphate, inosine, and inosine monophosphate, all of which are important to calculate freshness in seafood products. Similar applications of these technologies include investigating the molecular state of water in mackerel fillets after treatment with in-package dielectric barrier discharge generated plasma [193] assessing mobility of water during storage salted sardines [194], and determination of fat content in fish [195].

\subsection{Meat and Poultry Products}

This section will discuss the use of spectroscopic techniques for detecting and evaluating changes in the quality of meats following the application of thermal and non-thermal treatments.

\subsubsection{Thermal Treatments}

Quality assessment of meat products after the application of thermal treatments is a broad and extensively studied topic. The present overview represents merely a concise survey, organized by spectroscopic technique (Raman, NIR, MIR, Vis, fluorescence, and NMR); other works on this theme are reported in Table 4.

Raman Spectroscopy: As widely described above, meat products often undergo thermal treatments, such as microwave or ohmic heating, which obviously modify the structure of the aliment, in particular, at the protein structure level. For this reason, the characteristics of meat products during or after the application of thermal treatments are monitored by Raman spectroscopy, which is particularly suitable at inspecting secondary and tertiary protein structures [196] and it is therefore exceptionally useful for the investigation of muscle foods [155]. For instance, Shao and collaborator have used this technique to investigate the changings in meat batters after heating (70 ${ }^{\circ} \mathrm{C}$ for $30 \mathrm{~min}$ ) [197]. Analysis of variance (ANOVA) highlighted samples prepared with soybean oil or pork fat present a decrease in $\alpha$-helix content and an increase in $\beta$-sheet. The same conclusions were also reached by other authors; for instance, by Wang et al. [198] or by Xu and collaborators [199] who focused on the changes in myofibrillar proteins induced by heating, on chicken [198], and pork meat [199], respectively. Furthermore, in the study proposed by $\mathrm{Xu}$ and coauthors a deeper inspection of the Raman spectra was allowed by means of PCA. This explorative method disclosed hardness of meat was correlated with the $\beta$-sheet and $\beta$-turns amount, and anticorrelated with the $\alpha$-helix content. Additionally, the scores-plot inspection highlighted there was a clear spread of samples along PC1 according to their heating degree. In a similar scenario, Berhe and others applied PCA to Raman spectra in order to investigate the effects of cooking temperature and time on meat proteins [200]; the authors concluded the cooking temperature has a greater repercussion on the tyrosine and tryptophan ratio.

Vis/NIR/MIR: The suitability of these approaches is provided by the specificity of MIR, and, to a lesser extent, of NIR, for the proteins and polypeptides structures [201,202]. Although NIR signals are not directly relatable to specific compounds, Ellekjaer and Isaksson [203] showed that it was possible to assess maximum cooking temperatures in heat treated beef with a prediction error of $2.0^{\circ} \mathrm{C}$ in the temperature range $50-85^{\circ} \mathrm{C}$. More recently, González and collaborators demonstrated that the technique can be an efficient tool for investigating the modifications induced by oven-cooking in meat sensory characteristics [204]. In their study, pork loin samples were cooked in an oven at different 
conditions ( 150 or $180{ }^{\circ} \mathrm{C}$, for 45,60 , or $75 \mathrm{~min}$ ) or confit-cooked for 120,180 , or $240 \mathrm{~min}$. The samples were evaluated by trained panelists and analyzed by NIR spectroscopy. PCA highlighted the possibility of differentiating samples according to the cooking temperature. Moreover, the inspection of the score plots allowed distinguishing between oven and confit cooking procedures regardless of the other conditions, but it did not show grouping tendencies according to the diverse cooking times. Additionally, interesting findings came out by the multiblock [205] analysis of joint sensory and spectroscopic data. In fact, this allowed correlating the quantitative descriptive analysis (QDA) outcome with NIR spectra, providing indications about the positive/negative correlations among sensory attributes and absorption ranges. Calabrò and Magazù used FT-IR to compare the effect of cooking using conventional convective heating and microwave on meat [206]. In more detail, samples of breast bovine meat were cooked by microwave oven ( $800 \mathrm{~W}$ for $95 \mathrm{~s}$, or at $650 \mathrm{~W}$ for $160 \mathrm{~s}$ ) or by a traditional oven $\left(165^{\circ} \mathrm{C}\right.$ for $\left.16 \mathrm{~min}\right)$ and analyzed by MIR spectroscopy. The authors observed that the microwaved samples presented lower bands for $\mathrm{CH}_{2}$ of the methylene group, and carbonyl, probably due to uncompleted Maillard reaction, and increase of $\beta$-turns and $\beta$-sheets.

With the development of technologies and increased research of innovation in the gastronomic sector, novel refined cooking techniques are quite widespread, and deserved to be accounted. An example is the sous-vide approach, often used for cooking muscle food, in particular meat. In a recent study, Perez and collaborators investigated the texture characteristics of pork loin which underwent this treatment [207]. NIR spectra were collected on pork loins under vacuum cooked at different times $(1,2,4,6$, or $8 \mathrm{~h})$. Additionally, other parameters, such as moisture, $\mathrm{pH}$, cooking loss, and collagen were estimated, together with the texture profile and sensory analysis. PCA analysis applied to the texture highlighted sample grouping according to the cooking time; moreover, it indicated that short-cooked samples $(<2 \mathrm{~h})$ presented the most parsimonious cooking loss and appeared less tough and fibrous than other samples. The explorative analysis of NIR spectra allowed finding out the variables contributing the most to the PCA model; these were the bands between 880 and $890 \mathrm{~nm}$ and those between 910 and $920 \mathrm{~nm}$, associable to C-H bonds, and absorptions between 960 and $980 \mathrm{~nm}$ and 1010 and $1030 \mathrm{~nm}$, relatable to O-H and N-H bonds.

It is well-known that thermal treatments do not affect only proteins' structures, but also moisture content, which is a relevant quality parameter that strongly affects the organoleptic characteristics of meat. In this regard, Kandpal and others proposed a valuable study, where an HSI was used to assess moisture distribution in chicken breast [208]. Thirty-six chicken breasts were oven-cooked at three different temperatures $\left(50,60\right.$, and $70{ }^{\circ} \mathrm{C}$ ) and then analyzed by HSI. Hyperspectral images were collected in the Vis-NIR range $(400-1000 \mathrm{~nm})$ and moisture content was quantified according to the association of official analytical chemists (AOAC) recommendations. Eventually, moisture was also predicted from the hyperspectral data by means of PLSR. The regression model achieved successful results, providing a $R^{2}$ p of 0.90 . As expected, the water content strongly decreases with the increase of cooking temperature; samples cooked at $50{ }^{\circ} \mathrm{C}$ presented around $70 \%$ of the initial moisture, whereas those cooked at $70{ }^{\circ} \mathrm{C}$ had around $63 \%$ of it. This outcome is clearly visible in the water dispersion map shown in Figure 3. 
$70-73 \%$ water

(a)

(b)

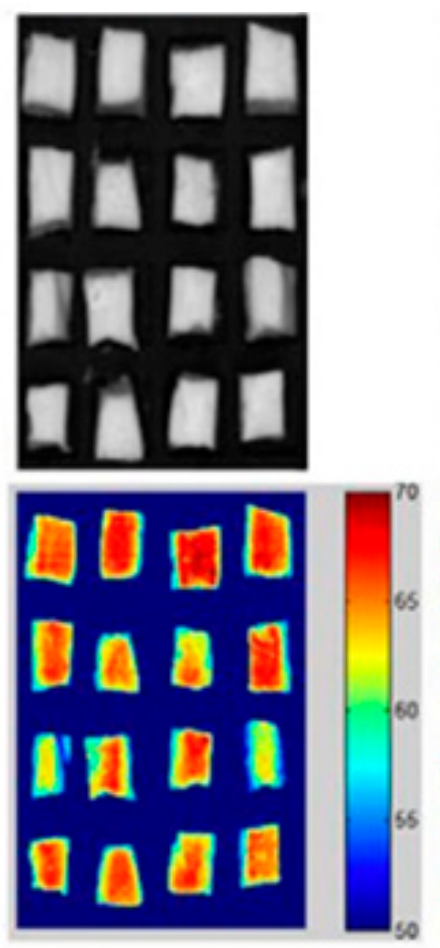

$50{ }^{\circ} \mathrm{C}$ image
$67-69 \%$ water
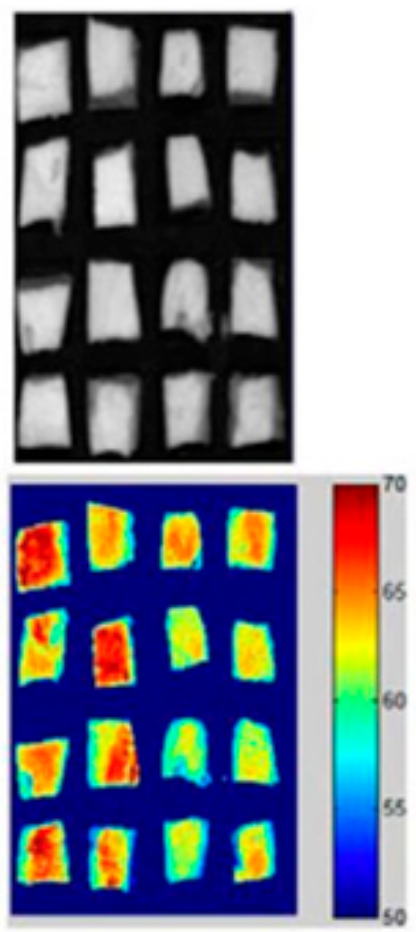

$60{ }^{\circ} \mathrm{C}$ image
$63-66 \%$ water
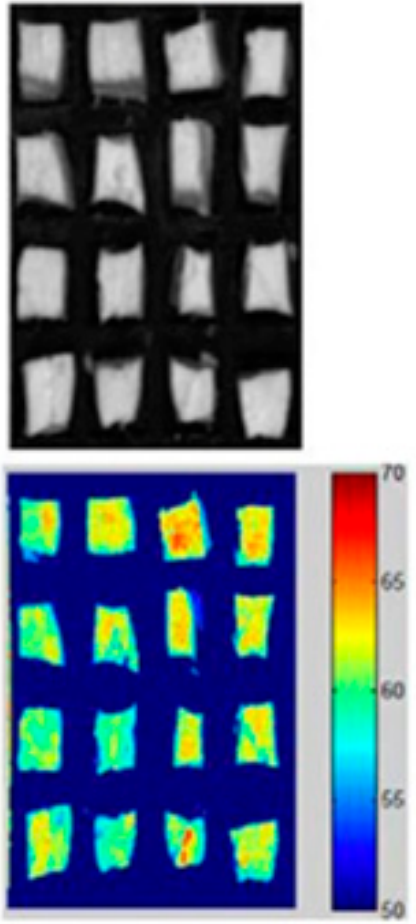

$70{ }^{\circ} \mathrm{C}$ image

Figure 3. Hyperspectral images of chicken breasts (a), and water dispersion map of chicken breasts (b). Adapted from [208].

In the bottom plots, red pixels are directly proportional to moisture. From this graphical representation it is evident that, at lower temperatures, moisture is spread all over the breast, in particular in the central area; on the other hand, higher temperature diminishes the water content, which is strongly reduced at $70{ }^{\circ} \mathrm{C}$. In a similar context lays the work from Liu and coauthors who exploited HSI to investigate moisture distribution in beef during microwave heating [209].

Furthermore, two other relevant studies on this regard can be found in the literature. These works focused on NIR analysis of baked liver pâté and sausages during heat treatment [210]. One of the peculiarities of these papers is that they were conducted in industrial conditions or similar environments (conveyor belts). In [210], baked liver pâté samples were investigated by a noncontact system collecting spectra in the range 760-1040 nm. NIR signals were used to create a PLS predictive model to estimate the temperature of meat samples; the RMSEP obtained was $2.66^{\circ} \mathrm{C}$. Similarly, in [211], an in-line NIR device was exploited for the assessment of the core temperature in sausages at the final stage of heating in an industrial oven. Measurements were collected in a similar spectral range as before (761-1081 nm) on samples presenting diverse temperatures (between 60 and $90{ }^{\circ} \mathrm{C}$ ). The proposed approach was definitely successful; in fact, it allowed predicting core temperatures with an accuracy of $\pm 1{ }^{\circ} \mathrm{C}$.

Fluorescence Spectroscopy: Front-face fluorescence (in EEM mode) has been widely used to examine the effect of heating procedures on meat. Sahar has conducted, together with different collaborators, several fluorescence-based studies on thermal effects on meat. In the most recent one [168], EEM spectra were collected on beef longissimus dorsi muscle cooked at 66,90 , or $237^{\circ} \mathrm{C}$ for $1,2,5,7$, or $10 \mathrm{~min}$. PCA and parallel factors (PARAFAC) analysis were run on data. In agreement with precedent work [212], explorative analysis allowed discriminating samples according to the cooking time. The inspection of PARAFAC components indicates that the most relevant contributions to the model are given by tryptophan (excitation: $297 \mathrm{~nm}$; emission: $327 \mathrm{~nm}$ ) and to peaks (excitation: $468 \mathrm{~nm}$; emission: $538 \mathrm{~nm}$ ) tentatively associated by the authors (in agreement with the literature) to 
hydroxymethylfurfural (HMF). Other relevant EEM bands are between 325-400 and 395-470 nm, probably relatable to oxidation of lipids. In another work, Sahar used EEM (coupled with N-PLS) to investigate a family of mutagens and carcinogens compounds, the heterocyclic amines, developed by grilled meat [213]. Similarly, fluorescence was used by Yamaguchi and others to determine toxic compounds (by-products of Maillard reactions) in cooked meat [214] and by Mitra and coauthors to investigate peptide oxidation (due to thermal treatments) [215].

Moreover, this technique has been used to study the impact of home cooking conditions by investigating fluorescence compounds produced during Maillard reactions. An example in this regard is the work Trevisan and collaborators [216], conducted on beef burgers. In this study the authors observed that, when the internal part of meat samples reaches temperatures lower than $90^{\circ} \mathrm{C}$ (by grilling or frying), there was an increase in furosine; on the other hand, at higher temperatures (between 90 and $100^{\circ} \mathrm{C}$ ), the amount of this compound decreases. When burgers were oven cooked at $300^{\circ} \mathrm{C}$, an increase in carboxymethyllysine content was detected. Moreover, the authors noticed that, regardless of the cooking conditions, the acrylamide content was parsimonious in all cases. The results showed that boiling was the cooking procedure that resulted in the lowest amount of Maillard by-products. In a similar context, fluorescence was also used to investigate the formation of Schiff base structures (as in seafood) during processing of chicken patties in a study proposed by Ferreira and collaborators [217]. In this work, the extent of proteins oxidation caused by diverse cooking procedures (grilling, roasting, boiling, and microwaving) was investigated. The authors concluded that, regardless of the cooking treatment, oxidation occurs, and chilling enlarges the oxidation effects, making chicken fleshes harder.

Nuclear Magnetic Resonance (NMR): NMR has been exploited for inspecting the effects of thermal treatments on meat products, in particular for studying water distribution in processed fleshes. One example is the work conducted by Liu and collaborators, who used this technique to investigate the water dispersion in beef braised at different temperatures (from 45 to $95^{\circ} \mathrm{C}$ using $10{ }^{\circ} \mathrm{C}$ steps) for diverse period of time (from 30 to $120 \mathrm{~min}$ by $30 \mathrm{~min}$ steps) [218]. The analysis revealed that $T_{2}$ was correlated with temperature. A PCA model on the relaxation times allowed recognizing samples spread along PC1 according to the cooking temperature; the authors concluded that water mobility and distribution are affected by this factor, while cooking time seems to have limited consequence on the dispersion of water in the meat. In a similar context lays the study by Han and others who used NMR to monitor the variations in terms of water migration and protein structure during heat-related gelation in meat batters [219]. The authors observed that the development of gel is induced by the production of $\beta$-sheets (by means of transformation of $\alpha$-helix) and by water transfer outside meat. In particular, different processes take place at diverse temperatures. In a first stage, between 39 and $50{ }^{\circ} \mathrm{C}$, proteins start denaturating and an increasing amount of bound-water is made free. Then, between 50 and $74{ }^{\circ} \mathrm{C}$, proteins agglomerate and $\beta$-sheets amount increase. 


\subsubsection{Non-Thermal Treatments}

Although heat treatments cause huge modifications in muscle foods, other physical processes can also affect the characteristics of these aliments. The effects of the main non-thermal treatments (HPP, MAP, cold-plasma, and ultrasound) on meat have been mainly studied by FT-IR and NMR, taking advantage of their already explained characteristics.

Some studies have also investigated the potential of Raman spectroscopy for monitoring changes occurring during the use of non-thermal treatments. For example, resonance Raman spectroscopy was used to investigate the color changes in pork upon treatment with HPP (600-700 MPa) [220]. Using a $413 \mathrm{~nm}$ excitation probe the authors found that the band frequencies in the 1300 and $1700 \mathrm{~cm}^{-1}$ region are important to elucidate the coordination and oxidation state of iron in hemoproteins. An upshift in frequencies at 1473 and $1564 \mathrm{~cm}^{-1}$ to bands at 1493 and $1581 \mathrm{~cm}^{-1}$ upon HPP treatment indicated a transition of deoxymyoglobin from the five-coordinated high spin to a six-coordinated low spin configuration. Other upshifts reported HPP treated meat are from $1356 \mathrm{~cm}^{-1}$ to 1359 and $1363 \mathrm{~cm}^{-1}$ and from $1524 \mathrm{~cm}^{-1}$ to 1552 and $1558 \mathrm{~cm}^{-1}$ (for both 600 and $700 \mathrm{MPa}$, respectively).

The impact of HPP on meat has been investigated by many authors using IR-spectroscopy; for instance, by Sazonova and collaborators who analyzed raw, cooked $\left(85 \pm 2{ }^{\circ} \mathrm{C}\right.$ for $\left.10 \mathrm{~min}\right)$, and HPP (two-different conditions: 300 or $600 \mathrm{MPa}$, for 1 or $15 \mathrm{~min}$ ) pork chops by FT-IR spectroscopy and colorimetry [221]. This latter technique showed that the pressure was directly correlated with discoloration of the meat. On the other hand, IR-analysis highlighted pressure and its time of application decrease the presence of $\alpha$-helix and $\beta$-sheet structures; nevertheless, the lowest amounts were found in cooked samples. This outcome regarded both spectra collected on meat and on juices. Moreover, it was observed that the intensity of absorption bands associated to collagen type I (between 1655 and $1454 \mathrm{~cm}^{-1}$ ) decreases with the increase of pressure, probably due to the move of denaturated collagen to the juices. On the other hand, in spectra collected on juices, the absorption peak at around $1394 \mathrm{~cm}^{-1}$ (relatable to $\mathrm{CH}_{3}$ in proteins and lipids) increased with the pressure. FT-IR analysis was exploited also in the study by Pavli and coauthors who investigated the spoilage of ham, either HPP treated or not, stored in diverse packages and for different periods of time [222]. Microbiological analysis of TVC and lactic acid bacteria (LAB) were evaluated on the same samples. PLS was used to fit TVC and LAB to IR-spectra.

In the literature it is possible to find several papers investigating modifications induced by storage and packaging by use of spectroscopy (Table 4). FT-IR plays a key role in this context; for example, in the study proposed by Amour and others, FT-IR was exploited for monitoring the spoilage of beef meat contained in different packaging (aerobically, MAP, and using an active packaging) [223]. Among the other outcomes, the authors pointed out that FT-IR coupled with chemometrics could be a suitable tool for predicting the spoilage of beef samples; additionally, they highlighted the spectral variables that contributed the most to this prediction: the peak around $1550 \mathrm{~cm}^{-1}$ (associable to the $\mathrm{C}-\mathrm{N}$ stretching), the one around $1458 \mathrm{~cm}^{-1}$ (relatable to $\mathrm{CH}_{2}$ scissoring in lipids), and the absorptions bands at 1311 and $1246 \mathrm{~cm}^{-1}$, respectively, probably due to the $\mathrm{C}-\mathrm{N}$ stretching in amines. 
Table 4. Some examples of application of spectroscopic methods for monitoring thermal and non-thermal treatments in meat.

\begin{tabular}{|c|c|c|c|c|}
\hline Muscle Foods & $\begin{array}{l}\text { Analytical } \\
\text { Technique }\end{array}$ & Chemometric Tool & Main Findings & Reference \\
\hline Pork batters & NMR; FT-IR & ANOVA & $\begin{array}{c}\text { With increasing temperatures, bonded-water converted into free } \\
\text { water, WHC increased significantly, and } \alpha \text {-helix transformed into } \\
\beta \text {-sheets. Correlations were observed between spectral data and } \\
\text { traditional parameters }\end{array}$ & [219] \\
\hline Pork & NMR & PLSR & $\begin{array}{l}\text { LF-NMR } T_{2} \text { relaxation is highly correlated to sensory attributes of } \\
\text { pork. Reduction in juiciness and tenderness at } 75^{\circ} \mathrm{C} \text { as compared } \\
\text { to } 65^{\circ} \mathrm{C} \text { was attributed to changes in the size of the pores } \\
\text { confining the myofibrillar water within the meat in combination } \\
\text { with an expulsion of water }\end{array}$ & [224] \\
\hline Pork loins Longissimus dorsi & Fluorescence & ANOVA & $\begin{array}{c}\text { Oxidative damages increased with increasing cooking } \\
\text { temperatures and cooking times }\end{array}$ & [215] \\
\hline Pork muscle & Raman; EEM & PCA, PLSR, PLS-DA & $\begin{array}{l}\text { It was possible to classify stored samples according to cooking } \\
\text { temperatures (below or above } 65^{\circ} \mathrm{C} \text { ) }\end{array}$ & [225] \\
\hline $\begin{array}{l}\text { Biceps femoris from Charolais } \\
\text { cow }\end{array}$ & MRI & - & $\begin{array}{l}\text { MRI allowed tracing thermal history of samples and provided } \\
\text { insights into the mechanisms linking temperature, deformation, } \\
\text { and water content during meat heating }\end{array}$ & [226] \\
\hline Pork & LF-NMR & PCA & $\begin{array}{l}\text { Heat-induced gelation of myofibrillar proteins led to diverse gel } \\
\text { network structures. NMR } T_{2} \text { parameters and microstructural } \\
\text { data were strongly correlated }\end{array}$ & [227] \\
\hline Sheep meat & Raman & PLSR & $\begin{array}{l}\text { Raman can be used to predict tenderness and cooking loss. High } \\
\text { correlations were observed between Raman data and shear force } \\
\text { and cooking loss }\end{array}$ & [228] \\
\hline $\begin{array}{l}\text { Porcine musculus longissimus } \\
\text { dorsi }\end{array}$ & Fluorescence & ANCOVA & $\begin{array}{c}\text { Modified atmosphere with high oxygen concentrations inhibited } \\
\text { (quenched) the fluorescence emission of zinc protoporphyrin and } \\
\text { protoporphyrin IX. Porphyrin fluorescence can be used as an } \\
\text { indicator for storage-related changes }\end{array}$ & [229] \\
\hline Beef & Raman & ANOVA, PLSR & $\begin{array}{l}\text { Raman spectra can be used to predict TVC and LAB in samples } \\
\text { packed under vacuum-packed and MAP, thus the technique } \\
\text { could predict meat spoilage }\end{array}$ & [230] \\
\hline Beef & NIR, MIR & PCA & $\begin{array}{l}\text { Similar results were obtained from both NIR and MIR, indicating } \\
\text { the possibility of using these techniques to support conventional } \\
\text { techniques in determining the shelf life of minced meat }\end{array}$ & [231] \\
\hline Chicken & Raman & ROC, MCR-ALS & $\begin{array}{l}\text { Band changes of amide I were used to show protein denaturation } \\
\text { occurring during heat treatments. The end point temperature was } \\
\text { accurately estimated }\end{array}$ & [232] \\
\hline
\end{tabular}


Other studies have investigated the impact of storage under MAP or other conditions on the quality of meats. For instance, being stored under MAP, meat is prone to changes in color; consequently, Vis spectroscopy could represent an alternative ally to inspect the quality of stored meat. This premise has been confirmed by Spanos and collaborators, who collected Vis spectra on pork steaks stored at diverse conditions in terms of storage time and MAP (atmosphere: $0 \%, 40 \%, 50 \%$, or $80 \%$ of oxygen; light: yes or no; storage time: up to 9 days) [233]. PCA unveiled that color modifications occurred at any level of oxygen and they were influenced by all the three investigated factors (i.e., MAP, time, and light). In the same study, PLS-DA was successfully used to classify samples according to the different storage conditions, confirming the outcomes obtained by the PCA models.

In addition to playing a key role in studying the effects of HPP and MAP, FT-IR spectroscopy is a suitable ally also for investigating the effect cold-plasma on meat products. An example of its exploitation is given by the study conducted by Sarangapani and collaborator who used FT-IR coupled with NMR and chromatography to inspect the modification induced by cold plasma on beef fats [234]. The authors found that the formation of hydroperoxides, along with the other oxidation products (e.g., ozonides, aldehydes, carboxylic acids), determined from the spectral results were proportional to the treatment time and its voltage. The IR spectra of beef fat treated by cold plasma-dielectric barrier discharge $\left((60-80 \mathrm{kV})\right.$ and treatment duration in the range of 3-30 min at temperature of $\left.16-18^{\circ} \mathrm{C}\right)$ indicated a decrease in $\mathrm{C}=\mathrm{C}$ (at 723,1650, and $3008 \mathrm{~cm}^{-1}$ ) with the increase in treatment intensity [234]. However, using the spectra data in the region between 1800 and $700 \mathrm{~cm}^{-1}$ in a PCA analysis was not successful in separating beef plasma treated samples and controls.

The effect of another non-thermal treatment, the ultrasounds, has been investigated by Kang et al. [235]. In this study, FT-IR was used to monitor the modifications induced in beef meat following the use of power ultrasound intensity (PUS). The study showed that the application of PUS induced proteins aggregation, with a transformation of $\alpha$-helix in $\beta$-sheets, leading to the formation of free radicals. Lipid and protein oxidation were also significantly increased as a result of application of PUS.

In another study, IR thermographic imaging was used to determine the heat transfer from the surface of samples to a surrounding medium and the heat transfer from the inner of the sample to its surface [236]. The technique was used to investigate the effect of ultrasound treatment ( 25 and $130 \mathrm{kHz}$ ) on the chilling of chicken breast. The use of ultrasound intensity of $130 \mathrm{kHz}$ was found to reduce the surface temperature of the chicken breast samples by $19.6 \%$, to increase water absorption by $113 \%$, and to produce more uniform cooling rate (around 22.3\%) compared to untreated controls.

The impact of ultrasound treatment combined with potassium alginate margination on chicken breasts meat samples was also assessed by fluorescence and NMR techniques in a recent study conducted by Shi and others [237]. Changes in fluorescence intensity of tryptophan provided valuable information about the modifications in the environment of aromatic residues of proteins, while NMR spectroscopy provided further information about the water-binding characteristics of meat tissue and protein integrity, occurring under the different applied treatments.

Several non-thermal processing techniques that rely on radiolysis (UV and irradiation), electric (e.g., pulsed electric field and high voltage arc discharge), ultrasound, HPP, and plasma treatments can produce radical species. The produced radical species can impact the quality of food and can be measured by electron spin resonance (ESR) $[149,238]$, although only few studies have been reported in this regard [239-241]. Bolumar and coworkers [240] demonstrated the onset of lipid oxidation in meat after HPP treatment and radicals (generated from protein and iron) were found in the myofibrillar and sarcoplasmic protein fraction. The treatment intensity in terms of time, temperature, and HPP all can increase the formation of radicals in meat [239]. Research on free radicals' generation in other emerging technologies is needed to understand their subsequent effects on muscle foods.

The effects of PEF on meat has not been widely studied yet. One of the few examples where spectroscopy has been used in this regard is the study conducted by O'Dowd and coauthors who used a colorimeter to investigate color changes after PEF treatment [242]. The authors concluded that the 
observed differences were not different from those caused by a water bath (at the same $\Delta \mathrm{t}$ ). In the same study, also NMR was used to investigate water migration. In agreement with the literature, it has been observed that PEF does not affect $T_{2}$ times, suggesting this non-thermal treatment does not induce modification in cell-membranes. Another recent NMR-based study has been proposed by Mungure and others [243] and it focused on the effects induced by low $(2.5 \mathrm{kV}, 50 \mathrm{~Hz}, 20 \mu \mathrm{s})$ and high $(10 \mathrm{kV}$, $50 \mathrm{~Hz}, 20 \mu \mathrm{s})$ PEF on red deer meat. The results showed that the meat tenderness was improved by the high PEF treatments, while the NMR-based metabolomics showed no effect due to PEF treatment.

\section{Conclusions and Future Trends}

This review provided an overview of spectroscopic techniques used to monitor changes in muscle foods, (e.g., fish, meat, and derivative products), as induced by the application of thermal and non-thermal treatments. Quality retention and shelf life extension of muscle foods require both adequate processing/preservation methods and rapid assessment techniques. Product damages caused by the use of conventional thermal treatment methods have driven the development of novel thermal and non-thermal technologies. Microwave, radio frequency, ohmic, and infrared heating are among the most applied novel thermal techniques, while modified atmosphere packaging, high pressure processing, ultrasounds, cold plasma, and pulsed electric field are the most commonly known novel non-thermal techniques. Several studies have reported that these new technologies cause less damage to foods in terms of sensory and nutritional characteristics compared to traditional processing methods.

On the other hand, the limitations related to the destructive nature of traditional measurements and the long time required to perform these measurements can be overcome by using spectroscopic techniques. Indeed, several spectroscopic techniques such as vibrational spectroscopy, fluorescence, and NMR have shown the potential to detect changes in quality resulting from processing. It is worth noting that the information obtained from spectroscopic techniques is not only associated with changes in the chemical composition but also to structural and other physical properties, enabling obtaining of spectra that are unique to the sample under investigation, acting as a fingerprint. Thus, in the light of the reviewed literature, it appears that spectroscopic techniques can provide alternatives to traditional sensory, microbiological, and physico-chemical assessment methods. Especially hyperspectral imaging (HSI) seems to be the most promising and investigated technique so far due to its well-known features, namely the capability to provide spectral and spatial information of the scanned samples and the possibility to be applied inline of production when the samples are moved on conveyor belts, for example. Moreover, the distribution map, or the chemical images that can be generated after the application of multivariate classification or regression models to the hyperspectral data, facilitate the visualization of the different measured parameters over the entire scanned samples. That is why the number of studies dealing with the application of spectroscopic techniques has been increasing in recent years, in the area of muscle foods or other food products.

However, these new technologies (processing and assessment methods) are not without drawbacks and only a few applications can be found at the industrial scale. The challenges that can be met might be summed up in three levels; the muscle food level, processing technology level, and assessment or analytical method level.

From the muscle food matrix point of view, the heterogeneity of muscle foods in terms of size, shape, and chemical composition remains one of the main challenges. This makes it challenging to both apply processing techniques and measure their impact on the treated samples. This problem can be reduced by using HSI or multispectral imaging. Although some investigations have been carried out aiming at applying HSI with visible and near infrared, very limited research has examined HSI in fluorescence or Raman mode. Therefore, it is our opinion that the possibility of coupling HSI with other spectroscopic techniques should be investigated more in future research.

From the processing point of view, there is a major issue related to the consumer perception of novel technologies due to concerns about food safety [10]. Public health issues have become even more politicized in the present time with the current COVID-19 crisis ranging around the world and 
affecting every aspect of life, including food choices and nutrition habits. Therefore, consumer doubt toward new technologies should be eliminated by clearly demonstrating the benefits of these new technologies on sensory and nutritional quality without compromising the safety of the processed products. From the reviewed literature, it can be noticed that some thermal (e.g., microwaving) and non-thermal (e.g., modified atmosphere packaging) treatments have been widely documented and they have already been implemented in many industrial applications, whereas other new technologies (e.g., ohmic heating, cold plasma, etc.) are still under investigation and optimization of their processing conditions are required and expected in the coming years. The concept of hurdle technology by combining two or more thermal and non-thermal treatments should be further investigated in future studies so that even more extension of shelf life of muscle foods might be achieved.

Finally, from the analytical point of view, several limitations can be recognized. Taking monitoring thermal treatments as an example, different factors could affect the measurement. These include temperature before the measurement, thermal load during processing, variations in thickness and size of the sample, just to mention a few. The challenge becomes even more complex in the case of processed products (e.g., fish cakes, hamburger), which contain many ingredients and various chemical compositions. Although HSI showed promising results when applied to such products [153,211], more investigations about the most suitable chemometric tools, measurement modes (interactance, diffuse reflectance, transmittance), and economic benefits of using spectroscopic techniques compared to traditional analytical methods should be studied and reported. Another possible solution can be to expand the use of the hurdle concept, mentioned before for processing, to include assessment methods by using multiplatform approaches. Such analytical strategies have become more popular in recent years due to the development of data fusion techniques, among other advances.

In summary, the application of new technologies under industrial environments remain challenging and needs further optimization. Therefore, more research should be carried out focusing on inline application of assessment methods, with further investigation of emerging thermal and non-thermal processing technologies.

Author Contributions: Conceptualization and methodology, A.H.; software, K.H.; writing-original draft preparation, A.H., S.O., B.T., T.R., D.C., A.E.-D.B. and A.B.; writing-review and editing, J.P.W. and H.N.; supervision, H.N. and K.H.; project administration, H.N.; funding acquisition, J.P.W., K.H. and H.N. All authors have read and agreed to the published version of the manuscript.

Funding: This research received no external funding

Acknowledgments: This work was supported by the Norwegian Institute of Food, Fisheries, and Aquaculture Research (Nofima) through a Strategic Research Initiative Spectec Project: rapid and non-destructive measurements.

Conflicts of Interest: The authors declare no conflict of interest

\section{References}

1. Rahman, M.S. (Ed.) Handbook of Food Preservation, 3rd ed.; CRC Press Taylor \& Francis Group: Boca Raton, FL, USA, 2020; ISBN 9781498740487.

2. Kubo, M.T.; Siguemoto, É.S.; Funcia, E.S.; Augusto, P.E.; Curet, S.; Boillereaux, L.; Sastry, S.K.; Gut, J.A. Non-thermal effects of microwave and ohmic processing on microbial and enzyme inactivation: A critical review. Curr. Opin. Food Sci. 2020, 35, 36-48. [CrossRef]

3. Luo, J.; Taylor, C.; Nebl, T.; Ng, K.; Bennett, L.E. Effects of macro-nutrient, micro-nutrient composition and cooking conditions on in vitro digestibility of meat and aquatic dietary proteins. Food Chem. 2018, 254, 292-301. [CrossRef] [PubMed]

4. Rosnes, J.T.; Skåra, T.; Skipnes, D. Recent Advances in Minimal Heat Processing of Fish: Effects on Microbiological Activity and Safety. Food Bioprocess Technol. 2011, 4, 833-848. [CrossRef]

5. Méndez, M.I.M.; Abuín, J.M.G. Thermal processing of fishery products. In Thermal Food Processing: New Technologies and Quality Issues, Second Edition; Sun, D.-W., Ed.; CRC Press Taylor \& Francis Group: Boca Raton, FL, USA, 2012; pp. 249-271. ISBN 9781439876794. 
6. Hassoun, A.; Heia, K.; Lindberg, S.; Nilsen, H. Spectroscopic Techniques for Monitoring Thermal Treatments in Fish and Other Seafood: A Review of Recent Developments and Applications. Foods 2020, 6, 767. [CrossRef] [PubMed]

7. Sun, D.-W. (Ed.) Thermal Food Processing. New Technologies and Quality Issues; CRC Press Taylor@Francis Group: Boca Raton, FL, USA, 2012; ISBN 9781439876794.

8. Dominguez-Hernandez, E.; Salaseviciene, A.; Ertbjerg, P. Low-temperature long-time cooking of meat: Eating quality and underlying mechanisms. Meat Sci. 2018, 143, 104-113. [CrossRef]

9. Yu, T.Y.; Morton, J.D.; Clerens, S.; Dyer, J.M. Cooking-Induced Protein Modifications in Meat. Compr. Rev. Food Sci. Food Saf. 2017, 16, 141-159. [CrossRef]

10. Troy, D.J.; Ojha, K.S.; Kerry, J.P.; Tiwari, B.K. Sustainable and consumer-friendly emerging technologies for application within the meat industry: An overview. Meat Sci. 2016, 120, 2-9. [CrossRef]

11. Pasha, I.; Saeed, F.; Sultan, M.T.; Khan, M.R.; Rohi, M. Recent Developments in Minimal Processing: A Tool to Retain Nutritional Quality of Food. Crit. Rev. Food Sci. Nutr. 2014, 54, 340-351. [CrossRef]

12. Zhang, L.; Lan, R.; Zhang, B.; Erdogdu, F.; Wang, S. A comprehensive review on recent developments of radio frequency treatment for pasteurizing agricultural products. Crit. Rev. Food Sci. Nutr. 2020, 10, 1-15. [CrossRef]

13. Rastogi, N.K. Recent trends and developments in infrared heating in food processing. Crit. Rev. Food Sci. Nutr. 2012, 52, 737-760. [CrossRef]

14. Jiang, H.; Liu, Z.; Wang, S. Microwave processing: Effects and impacts on food components. Crit. Rev. Food Sci. Nutr. 2018, 58, 2476-2489. [CrossRef] [PubMed]

15. Zhao, Y.M.; de Alba, M.; Sun, D.W.; Tiwari, B. Principles and recent applications of novel non-thermal processing technologies for the fish industry-A review. Crit. Rev. Food Sci. Nutr. 2019, 59, 728-742. [CrossRef] [PubMed]

16. Olatunde, O.O.; Benjakul, S. Nonthermal Processes for Shelf-Life Extension of Seafoods: A Revisit. Compr. Rev. Food Sci. Food Saf. 2018, 17, 892-904. [CrossRef]

17. Pérez-Andrés, J.M.; Charoux, C.M.G.; Cullen, P.J.; Tiwari, B.K. Chemical Modifications of Lipids and Proteins by Nonthermal Food Processing Technologies. J. Agric. Food Chem. 2018, 66, 5041-5054. [CrossRef] [PubMed]

18. Režek Jambrak, A.; Vukušić, T.; Donsi, F.; Paniwnyk, L.; Djekic, I. Three Pillars of Novel Nonthermal Food Technologies: Food Safety, Quality, and Environment. J. Food Qual. 2018, 2018, 8619707. [CrossRef]

19. Chen, F; Zhang, M.; Fan, K.; Mujumdar, A.S. Non-thermal Technology and Heating Technology for Fresh Food Cooking in the Central Kitchen Processing: A Review. Food Rev. Int. 2020, 9129. [CrossRef]

20. Bhat, Z.F.; Morton, J.D.; Mason, S.L.; Bekhit, A.E.D.A. Current and future prospects for the use of pulsed electric field in the meat industry. Crit. Rev. Food Sci. Nutr. 2019, 59, 1660-1674. [CrossRef]

21. Kulawik, P.; Kumar Tiwari, B. Recent advancements in the application of non-thermal plasma technology for the seafood industry. Crit. Rev. Food Sci. Nutr. 2019, 59, 3199-3210. [CrossRef]

22. Gómez, B.; Munekata, P.E.S.; Gavahian, M.; Barba, F.J.; Martí-Quijal, F.J.; Bolumar, T.; Campagnol, P.C.B.; Tomasevic, I.; Lorenzo, J.M. Application of pulsed electric fields in meat and fish processing industries: An overview. Food Res. Int. 2019, 123, 95-105. [CrossRef]

23. Ghimire, S.; Flury, M.; Scheenstra, E.J.; Miles, C.A. Electrical Systems for Pulsed Electric Field Applications in the Food Industry: An Engineering Perspective; Elsevier Ltd.: Amsterdam, The Netherlands, 2020.

24. Pereira, R.N.; Vicente, A.A. Environmental impact of novel thermal and non-thermal technologies in food processing. Food Res. Int. 2010, 43, 1936-1943. [CrossRef]

25. Picart-Palmade, L.; Cunault, C.; Chevalier-Lucia, D.; Belleville, M.P.; Marchesseau, S. Potentialities and limits of some non-thermal technologies to improve sustainability of food processing. Front. Nutr. 2019, 5, 130. [CrossRef] [PubMed]

26. Borda, D.; Nicolau, A.I.; Raspor, P. (Eds.) Trends in Fish Processing Technologies; CRC Press Taylor \& Francis Group: Boca Raton, FL, USA, 2017; ISBN 9781498729178.

27. Ozogul, Y. (Ed.) Innovative Technologies in Seafood Processing; CRC Press: Boca Raton, FL, USA, 2019; ISBN 9780815366447.

28. Cummins, E.J.; Lyng, J.G. (Eds.) Emerging Technologies in Production, Processing Production, Processing and Technology; John Wiley \& Sons, Ltd.: Chichester, UK, 2017; ISBN 9781118350683.

29. Bekhit, A.E.-D.A. (Ed.) Advances in Meat Processing Technology; CRC Press Taylor \& Francis Group: Boca Raton, FL, USA, 2017. 
30. Fidel Toldrá, L.M.L.N. (Ed.) Advanced Technologies for Meat Processing, 2nd ed.; CRC Press Taylor \& Francis Group: Boca Raton, FL, USA, 2017; ISBN 9781498754590.

31. Hassoun, A.; Karoui, R. Quality evaluation of fish and other seafood by traditional and nondestructive instrumental methods: Advantages and limitations. Crit. Rev. Food Sci. Nutr. 2017, 57, 1976-1998. [CrossRef]

32. Fan, H.; Fan, D.; Huang, J.; Zhao, J.; Yan, B.; Ma, S.; Zhou, W.; Zhang, H. Cooking evaluation of crayfish (Procambarus clarkia) subjected to microwave and conduction heating: A visualized strategy to understand the heat-induced quality changes of food. Innov. Food Sci. Emerg. Technol. 2020, 62, 102368. [CrossRef]

33. Hassoun, A.; Sahar, A.; Lakhal, L.; Ait-Kaddour, A. Fluorescence spectroscopy as a rapid and non-destructive method for monitoring quality and authenticity of fish and meat products: Impact of different preservation conditions. LWT 2019, 103, 279-292. [CrossRef]

34. Cheng, J.H.; Sun, D.W. Recent Applications of Spectroscopic and Hyperspectral Imaging Techniques with Chemometric Analysis for Rapid Inspection of Microbial Spoilage in Muscle Foods. Compr. Rev. Food Sci. Food Saf. 2015, 14, 478-490. [CrossRef]

35. Feng, C.-H.; Makino, Y.; Oshita, S.; García Martín, J.F. Hyperspectral imaging and multispectral imaging as the novel techniques for detecting defects in raw and processed meat products: Current state-of-the-art research advances. Food Control 2018, 84, 165-176. [CrossRef]

36. Liu, Y.; Pu, H.; Sun, D.-W. Hyperspectral imaging technique for evaluating food quality and safety during various processes: A review of recent applications. Trends Food Sci. Technol. 2017, 69, 25-35. [CrossRef]

37. Wu, D.; Sun, D.-W. Advanced applications of hyperspectral imaging technology for food quality and safety analysis and assessment: A review-Part II: Applications. Innov. Food Sci. Emerg. Technol. 2013, 19, 15-28. [CrossRef]

38. Hernández-Hernández, H.M.; Moreno-Vilet, L.; Villanueva-Rodríguez, S.J. Current status of emerging food processing technologies in Latin America: Novel non-thermal processing. Innov. Food Sci. Emerg. Technol. 2019, 58, 102233. [CrossRef]

39. Zhang, Z.H.; Wang, L.H.; Zeng, X.A.; Han, Z.; Brennan, C.S. Non-thermal technologies and its current and future application in the food industry: A review. Int. J. Food Sci. Technol. 2019, 54, 1-13. [CrossRef]

40. He, H.J.; Wu, D.; Sun, D.W. Nondestructive Spectroscopic and Imaging Techniques for Quality Evaluation and Assessment of Fish and Fish Products. Crit. Rev. Food Sci. Nutr. 2015, 55, 864-886. [CrossRef] [PubMed]

41. Fu, X.; Chen, J. A Review of Hyperspectral Imaging for Chicken Meat Safety and Quality Evaluation: Application, Hardware, and Software. Compr. Rev. Food Sci. Food Saf. 2019, 18, 535-547. [CrossRef]

42. Wu, L.; Pu, H.; Sun, D.-W. Novel techniques for evaluating freshness quality attributes of fish: A review of recent developments. Trends Food Sci. Technol. 2019, 83, 259-273. [CrossRef]

43. Kucha, C.T.; Liu, L.; Ngadi, M.O. Non-destructive spectroscopic techniques and multivariate analysis for assessment of fat quality in pork and pork products: A review. Sensors 2018, 18, 377. [CrossRef] [PubMed]

44. Sobral, M.M.C.; Cunha, S.C.; Faria, M.A.; Ferreira, I.M.P.L.V.O. Domestic Cooking of Muscle Foods: Impact on Composition of Nutrients and Contaminants. Compr. Rev. Food Sci. Food Saf. 2018, 17, 309-333. [CrossRef]

45. Stormo, S.K.; Skåra, T.; Skipnes, D.; Sone, I.; Carlehög, M.; Heia, K.; Skjelvareid, M.H. In-Pack Surface Pasteurization of Capture-Based, Pre-Rigor Filleted Atlantic Cod (Gadus morhua). J. Aquat. Food Prod. Technol. 2018, 7, 783-794. [CrossRef]

46. Stormo, S.K.; Skipnes, D.; Sone, I.; Skuland, A.; Heia, K.; Skåra, T. Modeling-assisted minimal heat processing of Atlantic cod (Gadus morhua). J. Food Process Eng. 2017, 40, e12555. [CrossRef]

47. Cao, H.; Fan, D.; Jiao, X.; Huang, J.; Zhao, J.; Yan, B.; Zhou, W.; Zhang, W.; Zhang, H. Effects of microwave combined with conduction heating on surimi quality and morphology. J. Food Eng. 2018, 228, 1-11. [CrossRef]

48. Cao, H.; Fan, D.; Jiao, X.; Huang, J.; Zhao, J.; Yan, B.; Zhou, W.; Zhang, W.; Ye, W.; Zhang, H. Importance of thickness in electromagnetic properties and gel characteristics of surimi during microwave heating. J. Food Eng. 2019, 248, 80-88. [CrossRef]

49. Hu, L.; Ren, S.; Shen, Q.; Chen, J.; Ye, X.; Ling, J. Proteomic study of the effect of different cooking methods on protein oxidation in fish fillets. RSC Adv. 2017, 7, 27496-27505. [CrossRef]

50. Lerfall, J.; Jakobsen, A.N.; Skipnes, D.; Waldenstrøm, L.; Hoel, S.; Rotabakk, B.T. Comparative Evaluation on the Quality and Shelf life of Atlantic Salmon (Salmo salar L.) Filets Using Microwave and Conventional Pasteurization in Combination with Novel Packaging Methods. J. Food Sci. 2018, 83, 3099-3109. [CrossRef] [PubMed] 
51. Cai, L.; Feng, J.; Cao, A.; Zhang, Y.; Lv, Y.; Li, J. Denaturation Kinetics and Aggregation Mechanism of the Sarcoplasmic and Myofibril Proteins from Grass Carp During Microwave Processing. Food Bioprocess Technol. 2018, 11, 417-426. [CrossRef]

52. Blikra, M.J.; Skipnes, D.; Feyissa, A.H. Model for heat and mass transport during cooking of cod loin in a convection oven. Food Control 2019, 102, 29-37. [CrossRef]

53. Nieva-Echevarría, B.; Goicoechea, E.; Manzanos, M.J.; Guillén, M.D. Effects of different cooking methods on the lipids and volatile components of farmed and wild European sea bass (Dicentrarchus labrax). Food Res. Int. 2018, 103, 48-58. [CrossRef]

54. Dang, T.T.; Feyissa, A.H.; Gringer, N.; Jessen, F.; Olsen, K.; Bøknæs, N.; Orlien, V. Effects of high pressure and ohmic heating on shell loosening, thermal and structural properties of shrimp (Pandalus borealis). Innov. Food Sci. Emerg. Technol. 2020, 59, 102246. [CrossRef]

55. Tian, X.; Shao, L.; Yu, Q.; Li, W.S.X.; Dai, R. Comparative analysis of quality uniformity of ohmic and water bath heating treated pork batter with different fat content. J. Food Process. Preserv. 2020, 44, e14377. [CrossRef]

56. Tang, X.; Cronin, D.A.; Brunton, N.P. The effect of radio frequency heating on chemical, physical and sensory aspects of quality in turkey breast rolls. Food Chem. 2005, 93, 1-7. [CrossRef]

57. Muñoz, I.; Serra, X.; Guàrdia, M.D.; Fartdinov, D.; Arnau, J.; Picouet, P.A.; Gou, P. Radio frequency cooking of pork hams followed with conventional steam cooking. LWT 2020, 123, 109104. [CrossRef]

58. Rincon, A.M.; Singh, R.K. Inactivation of Shiga toxin-producing and nonpathogenic Escherichia coli in non-intact steaks cooked in a radio frequency oven. Food Control 2016, 62, 390-396. [CrossRef]

59. Yildiz Turp, G.; Icier, F.; Kor, G. Influence of infrared final cooking on color, texture and cooking characteristics of ohmically pre-cooked meatball. Meat Sci. 2016, 114, 46-53. [CrossRef]

60. Sengun, I.Y.; Icier, F.; Kor, G. Effects of Combined Ohmic-Infrared Cooking Treatment on Microbiological Inactivation of Meatballs. J. Food Process Eng. 2017, 40, e12309. [CrossRef]

61. Rahimi, D.; Kashaninejad, M.; Ziaiifar, A.M.; Mahoonak, A.S. Effect of infrared final cooking on some physico-chemical and engineering properties of partially fried chicken nugget. Innov. Food Sci. Emerg. Technol. 2018, 47, 1-8. [CrossRef]

62. Chizoba Ekezie, F.-G.; Sun, D.-W.; Han, Z.; Cheng, J.-H. Microwave-assisted food processing technologies for enhancing product quality and process efficiency: A review of recent developments. Trends Food Sci. Technol. 2017, 67, 58-69. [CrossRef]

63. Taşkıran, M.; Olum, E.; Candoğan, K. Changes in chicken meat proteins during microwave and electric oven cooking. J. Food Process. Preserv. 2020, 44, e14324. [CrossRef]

64. Wang, X.; Muhoza, B.; Wang, X.; Feng, T.; Xia, S.; Zhang, X. Comparison between microwave and traditional water bath cooking on saltiness perception, water distribution and microstructure of grass crap meat. Food Res. Int. 2019, 125, 108521. [CrossRef] [PubMed]

65. Guo, C.; Mujumdar, A.S.; Zhang, M. New Development in Radio Frequency Heating for Fresh Food Processing: A Review. Food Eng. Rev. 2019, 11, 29-43. [CrossRef]

66. Uemura, K.; Kanafusa, S.; Takahashi, C.; Kobayashi, I. Development of a radio frequency heating system for sterilization of vacuum-packed fish in water. Biosci. Biotechnol. Biochem. 2017, 81, 762-767. [CrossRef]

67. Llave, Y.; Liu, S.; Fukuoka, M.; Sakai, N. Computer simulation of radiofrequency defrosting of frozen foods. J. Food Eng. 2015, 152, 32-42. [CrossRef]

68. Yang, H.; Chen, Q.; Cao, H.; Fan, D.; Huang, J.; Zhao, J.; Yan, B.; Zhou, W.; Zhang, W.; Zhang, H. Radiofrequency Thawing of Frozen Minced Fish Based on the Dielectric Response Mechanism. Innov. Food Sci. Emerg. Technol. 2019, 52, 80-88. [CrossRef]

69. Ángel-Rendón, S.V.; Filomena-Ambrosio, A.; Cordon-Díaz, S.; Benítez-Sastoque, E.R.; Sotelo-Díaz, L.I. Ohmic cooking: Application of a novel technology in pork and influences on water holding capacity, cooking loss and colour. Int. J. Gastron. Food Sci. 2019, 17, 100164. [CrossRef]

70. Jaeger, H.; Roth, A.; Toepfl, S.; Holzhauser, T.; Engel, K.-H.; Knorr, D.; Vogel, R.F.; Bandick, N.; Kulling, S.; Heinz, V.; et al. Opinion on the use of ohmic heating for the treatment of foods. Trends Food Sci. Technol. 2016, 55, 84-97. [CrossRef]

71. Dai, Y.; Lu, Y.; Wu, W.; Lu, X.; Han, Z.; Liu, Y.; Li, X.; Dai, R. Changes in oxidation, color and texture deteriorations during refrigerated storage of ohmically and water bath-cooked pork meat. Innov. Food Sci. Emerg. Technol. 2014, 26, 341-346. [CrossRef] 
72. Aboud, S.A.; Altemimi, A.B.; Al-HiIphy, A.R.S.; Yi-Chen, L.; Cacciola, F. A comprehensive review on infrared heating applications in food processing. Molecules 2019, 24, 4125. [CrossRef] [PubMed]

73. Kor, G.; Icier, F. Thermal imaging during infrared final cooking of semi-processed cylindrical meat product. Infrared Phys. Technol. 2016, 79, 242-251. [CrossRef]

74. Kendirci, P.; Icier, F.; Kor, G.; Onogur, T.A. Influence of infrared final cooking on polycyclic aromatic hydrocarbon formation in ohmically pre-cooked beef meatballs. Meat Sci. 2014, 97, 123-129. [CrossRef] [PubMed]

75. Simonin, H.; Duranton, F.; de Lamballerie, M. New Insights into the High-Pressure Processing of Meat and Meat Products. Compr. Rev. Food Sci. Food Saf. 2012, 11, 285-306. [CrossRef]

76. Truong, B.Q.; Buckow, R.; Stathopoulos, C.E.; Nguyen, M.H. Advances in High-Pressure Processing of Fish Muscles. Food Eng. Rev. 2015, 7, 109-129. [CrossRef]

77. Campus, M. High Pressure Processing of Meat, Meat Products and Seafood. Food Eng. Rev. 2010, 2, $256-273$. [CrossRef]

78. Maldonado, J.A.; Schaffner, D.W.; Cuitinõ, A.M.; Karwe, M.V. In situ studies of microbial inactivation during high pressure processing. High Press. Res. 2016, 36, 79-89. [CrossRef]

79. Morton, J.D.; Lee, H.Y.Y.; Pearson, R.G.; Bickerstaffe, R. The physical and biochemical effects of pre-rigor high pressure processing of beef. Meat Sci. 2018, 143, 129-136. [CrossRef] [PubMed]

80. Morton, J.D.; Pearson, R.G.; Lee, H.Y.Y.; Smithson, S.; Mason, S.L.; Bickerstaffe, R. High pressure processing improves the tenderness and quality of hot-boned beef. Meat Sci. 2017, 133, 69-74. [CrossRef] [PubMed]

81. Zhan, X.; Sun, D.W.; Zhu, Z.; Wang, Q.J. Improving the quality and safety of frozen muscle foods by emerging freezing technologies: A review. Crit. Rev. Food Sci. Nutr. 2018, 58, 2925-2938. [CrossRef] [PubMed]

82. Aubourg, S.P.; Torres, J.A.; Saraiva, J.A.; Guerra-Rodríguez, E.; Vázquez, M. Effect of high-pressure treatments applied before freezing and frozen storage on the functional and sensory properties of Atlantic mackerel (Scomber scombrus). LWT Food Sci. Technol. 2013, 53, 100-106. [CrossRef]

83. Tironi, V.; De Lamballerie, M.; Le-Bail, A. Quality changes during the frozen storage of sea bass (Dicentrarchus labrax) muscle after pressure shift freezing and pressure assisted thawing. Innov. Food Sci. Emerg. Technol. 2010, 11, 565-573. [CrossRef]

84. Alarcon-Rojo, A.D.; Janacua, H.; Rodriguez, J.C.; Paniwnyk, L.; Mason, T.J. Power ultrasound in meat processing. Meat Sci. 2015, 107, 86-93. [CrossRef]

85. Barretto, T.L.; Pollonio, M.A.R.; Telis-Romero, J.; da Silva Barretto, A.C. Improving sensory acceptance and physicochemical properties by ultrasound application to restructured cooked ham with salt $(\mathrm{NaCl})$ reduction. Meat Sci. 2018, 145, 55-62. [CrossRef]

86. Pinton, M.B.; Correa, L.P.; Facchi, M.M.X.; Heck, R.T.; Leães, Y.S.V.; Cichoski, A.J.; Lorenzo, J.M.; dos Santos, M.; Pollonio, M.A.R.; Campagnol, P.C.B. Ultrasound: A new approach to reduce phosphate content of meat emulsions. Meat Sci. 2019, 152, 88-95. [CrossRef]

87. Inguglia, E.S.; Zhang, Z.; Burgess, C.; Kerry, J.P.; Tiwari, B.K. Influence of extrinsic operational parameters on salt diffusion during ultrasound assisted meat curing. Ultrasonics 2018, 83, 164-170. [CrossRef]

88. Lee, J.; Jo, K.; Lim, Y.; Jeon, H.J.; Choe, J.H.; Jo, C.; Jung, S. The use of atmospheric pressure plasma as a curing process for canned ground ham. Food Chem. 2018, 240, 430-436. [CrossRef]

89. Faridnia, F.; Ma, Q.L.; Bremer, P.J.; Burritt, D.J.; Hamid, N.; Oey, I. Effect of freezing as pre-treatment prior to pulsed electric field processing on quality traits of beef muscles. Innov. Food Sci. Emerg. Technol. 2015, 29, 31-40. [CrossRef]

90. Cooksey, K. Modified atmosphere packaging of meat, poultry and fish. In Innovations in Food Packaging; Han, J.H., Ed.; Academic Press: London, UK, 2014; pp. 475-493.

91. Belcher, J.N. Industrial packaging developments for the global meat market. Meat Sci. 2006, 74, $143-148$. [CrossRef] [PubMed]

92. Spanos, D.; Tørngren, M.A.; Christensen, M.; Baron, C.P. Effect of oxygen level on the oxidative stability of two different retail pork products stored using modified atmosphere packaging (MAP). Meat Sci. 2016, 113, 162-169. [CrossRef] [PubMed]

93. Argyri, A.A.; Papadopoulou, O.S.; Nisiotou, A.; Tassou, C.C.; Chorianopoulos, N. Effect of high pressure processing on the survival of Salmonella Enteritidis and shelf-life of chicken fillets. Food Microbiol. 2018, 70 , 55-64. [CrossRef] [PubMed] 
94. Rode, T.M.; Hovda, M.B. High pressure processing extend the shelf life of fresh salmon, cod and mackerel. Food Control 2016, 70, 242-248. [CrossRef]

95. Rode, T.M.; Rotabakk, B.T. Extending shelf life of desalted cod by high pressure processing. Innov. Food Sci. Emerg. Technol. 2020, 136126, in press. [CrossRef]

96. Zhang, Z.; Yang, Y.; Zhou, P.; Zhang, X.; Wang, J. Effects of high pressure modification on conformation and gelation properties of myofibrillar protein. Food Chem. 2017, 217, 678-686. [CrossRef]

97. Pedrós-Garrido, S.; Condón-Abanto, S.; Beltrán, J.A.; Lyng, J.G.; Brunton, N.P.; Bolton, D.; Whyte, P. Assessment of high intensity ultrasound for surface decontamination of salmon ( $S$. salar), mackerel (S. scombrus), cod (G. morhua) and hake (M. merluccius) fillets, and its impact on fish quality. Innov. Food Sci. Emerg. Technol. 2017, 41, 64-70. [CrossRef]

98. Vetchapitak, T.; Shinki, T.; Sasaki, S.; Taniguchi, T.; Luangtongkum, T.; Misawa, N. Evaluation of chemical treatment combined with vacuum and ultrasonication with a water resonance system for reducing Campylobacter on naturally contaminated chicken carcasses. Food Control 2020, 112, 107087. [CrossRef]

99. Xiong, G.; Fu, X.; Pan, D.; Qi, J.; Xu, X.; Jiang, X. Influence of ultrasound-assisted sodium bicarbonate marination on the curing efficiency of chicken breast meat. Ultrason. Sonochem. 2020, 60, 104808. [CrossRef]

100. Contreras-Lopez, G.; Carnero-Hernandez, A.; Huerta-Jimenez, M.; Alarcon-Rojo, A.D.; Garcia-Galicia, I.; Carrillo-López, L.M. High-intensity ultrasound applied on cured pork: Sensory and physicochemical characteristics. Food Sci. Nutr. 2020, 8, 786-795. [CrossRef]

101. Yong, H.I.; Lee, H.; Park, S.; Park, J.; Choe, W.; Jung, S.; Jo, C. Flexible thin-layer plasma inactivation of bacteria and mold survival in beef jerky packaging and its effects on the meat's physicochemical properties. Meat Sci. 2017, 123, 151-156. [CrossRef] [PubMed]

102. Albertos, I.; Martin-Diana, A.B.; Cullen, P.J.; Tiwari, B.K.; Ojha, K.S.; Bourke, P.; Rico, D. Shelf-life extension of herring (Clupea harengus) using in-package atmospheric plasma technology. Innov. Food Sci. Emerg. Technol. 2019, 53, 85-91. [CrossRef]

103. Jo, K.; Lee, J.; Lee, S.; Lim, Y.; Choi, Y.S.; Jo, C.; Jung, S. Curing of ground ham by remote infusion of atmospheric non-thermal plasma. Food Chem. 2020, 309, 125643. [CrossRef]

104. Alahakoon, A.U.; Oey, I.; Bremer, P.; Silcock, P. Process optimisation of pulsed electric fields pre-treatment to reduce the sous vide processing time of beef briskets. Int. J. Food Sci. Technol. 2019, 54, 823-834. [CrossRef]

105. Zhou, Y.; He, Q.; Zhou, D. Optimization Extraction of Protein from Mussel by High-Intensity Pulsed Electric Fields. J. Food Process. Preserv. 2017, 41, e12962. [CrossRef]

106. Hultmann, L.; Rustad, T. Iced storage of Atlantic salmon (Salmo salar)—Effects on endogenous enzymes and their impact on muscle proteins and texture. Food Chem. 2004, 87, 31-41. [CrossRef]

107. AOAC. Association of Official Analytical Chemists; AOAC: Washington, DC, USA, 1990.

108. Bligh, E.G.; Dyer, W.J. A rapid method of total lipid extraction and purification. Can. J. Biochem. Physiol. 1959, 37, 911-917. [CrossRef]

109. Folch, J.; Lees, M.; Sloane Stanley, G. A simple method for the isolation and purification of total lipides from animal tissues. J. Biol. Chem. 1957, 226, 497-509.

110. Jensen, W.B. The Origin of the Soxhlet Extractor. J. Chem. Educ. 2007, 84, 1913. [CrossRef]

111. Duun, A.S.; Rustad, T. Quality changes during superchilled storage of cod (Gadus morhua) fillets. Food Chem. 2007, 105, 1067-1075. [CrossRef]

112. Cropotova, J.; Mozuraityte, R.; Standal, I.B.; Aftret, K.C.; Rustad, T. The Effect of Sous-Vide Cooking Parameters, Chilled Storage and Antioxidants on Quality Characteristics of Atlantic Mackerel (Scomber scombrus) in Relation to Structural Changes in Proteins. Food Technol. Biotechnol. 2019, 57, 191-199. [CrossRef] [PubMed]

113. Hultmann, L.; Rørå, A.M.B.; Steinsland, I.; Skåra, T.; Rustad, T. Proteolytic activity and properties of proteins in smoked salmon (Salmo salar)—Effects of smoking temperature. Food Chem. 2004, 85, 377-387. [CrossRef]

114. Nilsson, K.; Ekstrand, B. Enzyme leakage in muscle-tissue of rainbow-trout (oncorhynchus-mykiss) related to various thawing treatments. Z. Lebensm. Unters. Forsch. 1994, 198, 253-257. [CrossRef]

115. Li, Z.; Wang, J.; Zheng, B.; Guo, Z. Impact of combined ultrasound-microwave treatment on structural and functional properties of golden threadfin bream (Nemipterus virgatus) myofibrillar proteins and hydrolysates. Ultrason. Sonochem. 2020, 65, 105063. [CrossRef] [PubMed] 
116. Hassoun, A.; Karoui, R. Monitoring changes in whiting (Merlangius merlangus) fillets stored under modified atmosphere packaging by front face fluorescence spectroscopy and instrumental techniques. Food Chem. 2016, 200, 343-353. [CrossRef] [PubMed]

117. Maqsood, S.; Benjakul, S. Synergistic effect of tannic acid and modified atmospheric packaging on the prevention of lipid oxidation and quality losses of refrigerated striped catfish slices. Food Chem. 2010, 121, 29-38. [CrossRef]

118. Li, S.; Tang, S.; Yan, L.; Li, R. Effects of microwave heating on physicochemical properties, microstructure and volatile profiles of yak meat. J. Appl. Anim. Res. 2019, 47, 262-272. [CrossRef]

119. Hultmann, L.; Rustad, T. Textural Changes During Iced Storage of Salmon (Salmo salar) and Cod (Gadus morhua). J. Aquat. Food Prod. Technol. 2002, 11, 105-123. [CrossRef]

120. Ofstad, R.; Kidman, S.; Myklebust, R.; Hermansson, A.-M. Liquid Holding Capacity and Structural Changes During Heating of Fish Muscle: Cod (Gadus morhua L.) and Salmon (Salmo salar). Food Struct. 1993, 12, 163-174.

121. Sigurgisladottir, S.; Torrissen, O.; Lie, Ø.; Thomassen, M.; Hafsteinsson, H. Salmon quality: Methods to determine the quality parameters. Rev. Fish. Sci. 1997, 5, 223-252. [CrossRef]

122. Ofstad, R.; Kidman, S.; Myklebust, R.; Olsen, R.L.; Hermansson, A.M. Liquid-holding capacity and structural changes in comminuted salmon (Salmo salar) muscle as influenced by $\mathrm{pH}$, salt and temperature. LWT Food Sci. Technol. 1995, 28, 329-339. [CrossRef]

123. Cropotova, J.; Mozuraityte, R.; Standal, I.B.; Rustad, T. The Influence of Cooking Parameters and Chilled Storage Time on Quality of Sous-Vide Atlantic Mackerel (Scomber scombrus). J. Aquat. Food Prod. Technol. 2019, 28, 505-518. [CrossRef]

124. Hultmann, L.; Phu, T.M.; Tobiassen, T.; Aas-Hansen, O.; Rustad, T. Effects of pre-slaughter stress on proteolytic enzyme activities and muscle quality of farmed Atlantic cod (Gadus morhua). Food Chem. 2012, 134, 1399-1408. [CrossRef] [PubMed]

125. Martínez, M.A.; Velazquez, G.; Cando, D.; Núñez-Flores, R.; Borderías, A.J.; Moreno, H.M. Effects of high pressure processing on protein fractions of blue crab (Callinectes sapidus) meat. Innov. Food Sci. Emerg. Technol. 2017, 41, 323-329. [CrossRef]

126. Schubring, R.; Meyer, C.; Schlüter, O.; Boguslawski, S.; Knorr, D. Impact of high pressure assisted thawing on the quality of fillets from various fish species. Innov. Food Sci. Emerg. Technol. 2003, 4, 257-267. [CrossRef]

127. de Oliveira, F.A.; Neto, O.C.; dos Santos, L.M.R.; Ferreira, E.H.R.; Rosenthal, A. Effect of high pressure on fish meat quality-A review. Trends Food Sci. Technol. 2017, 66, 1-19. [CrossRef]

128. Roberts, J.J.; Cozzolino, D. An Overview on the Application of Chemometrics in Food Science and Technology-An Approach to Quantitative Data Analysis. Food Anal. Methods 2016, 9, 3258-3267. [CrossRef]

129. Wang, L.; Sun, D.W.; Pu, H.; Cheng, J.H. Quality analysis, classification, and authentication of liquid foods by near-infrared spectroscopy: A review of recent research developments. Crit. Rev. Food Sci. Nutr. 2017, 57, 1524-1538. [CrossRef]

130. Karoui, R.; Downey, G.; Blecker, C. Mid-infrared spectroscopy coupled with chemometrics: A tool for the analysis of intact food systems and the exploration of their molecular structure-quality relationships-A review. Chem. Rev. 2010, 110, 6144-6168. [CrossRef]

131. Grabska, J.; Huck, C.W. Near-Infrared Spectroscopy in Bio-Applications. Molecules 2020, 25, 2948.

132. Crocombe, R.A. Portable Spectroscopy. Appl. Spectrosc. 2018, 72, 1701-1751. [CrossRef] [PubMed]

133. Alander, J.T.; Bochko, V.; Martinkauppi, B.; Saranwong, S.; Mantere, T. A Review of Optical Nondestructive Visual and Near-Infrared Methods for Food Quality and Safety. Int. J. Spectrosc. 2013, 2013, 341402. [CrossRef]

134. Sorak, D.; Herberholz, L.; Iwascek, S.; Altinpinar, S.; Pfeifer, F.; Siesler, H.W. New developments and applications of handheld raman, mid-infrared, and near-infrared spectrometers. Appl. Spectrosc. Rev. 2012, 47, 83-115. [CrossRef]

135. Cozzolino, D. The role of vibrational spectroscopy as a tool to assess economically motivated fraud and counterfeit issues in agricultural products and foods. Anal. Methods 2015, 7, 9390-9400. [CrossRef]

136. Rolinger, L.; Rüdt, M.; Hubbuch, J. A critical review of recent trends, and a future perspective of optical spectroscopy as PAT in biopharmaceutical downstream processing. Anal. Bioanal. Chem. 2020, 412, 2047-2064. [CrossRef] 
137. Nicolaï, B.M.; Beullens, K.; Bobelyn, E.; Peirs, A.; Saeys, W.; Theron, K.I.; Lammertyn, J. Nondestructive measurement of fruit and vegetable quality by means of NIR spectroscopy: A review. Postharvest Biol. Technol. 2007, 46, 99-118. [CrossRef]

138. Khakimov, B.; Bak, S.; Engelsen, S.B. High-throughput cereal metabolomics: Current analytical technologies, challenges and perspectives. J. Cereal Sci. 2014, 59, 393-418. [CrossRef]

139. Cattaneo, T.M.P.; Stellari, A. Review: NIR spectroscopy as a suitable tool for the investigation of the horticultural field. Agronomy 2019, 9, 503. [CrossRef]

140. Pasquini, C. Near infrared spectroscopy: A mature analytical technique with new perspectives-A review. Anal. Chim. Acta 2018, 1026, 8-36. [CrossRef]

141. Li, Y.S.; Church, J.S. Raman spectroscopy in the analysis of food and pharmaceutical nanomaterials. J. Food Drug Anal. 2014, 22, 29-48. [CrossRef]

142. Zheng, J.; He, L. Surface-Enhanced Raman Spectroscopy for the Chemical Analysis of Food. Compr. Rev. Food Sci. Food Saf. 2014, 13, 317-328. [CrossRef]

143. Qin, J.; Kim, M.S.; Chao, K.; Cho, B. Raman Chemical Imaging Technology for Food and Agricultural Applications. J. Biosyst. Eng. 2017, 42, 170-189. [CrossRef]

144. Grassi, S.; Casiraghi, E.; Alamprese, C. Handheld NIR device: A non-targeted approach to assess authenticity of fish fillets and patties. Food Chem. 2018, 243, 382-388. [CrossRef]

145. Beć, K.B.; Grabska, J.; Siesler, H.W.; Huck, C.W. Handheld near-infrared spectrometers: Where are we heading? NIR News 2020, 31, 28-35. [CrossRef]

146. Qin, J.; Kim, M.S.; Chao, K.; Schmidt, W.F.; Dhakal, S.; Cho, B.-K.; Peng, Y.; Huang, M. Subsurface inspection of food safety and quality using line-scan spatially offset Raman spectroscopy technique. Food Control 2017, 75, 246-254. [CrossRef]

147. Manley, M. Near-infrared spectroscopy and hyperspectral imaging: Non-destructive analysis of biological materials. Chem. Soc. Rev. 2014, 43, 8200-8214. [CrossRef]

148. Cozzolino, D.; Roberts, J. Applications and developments on the use of vibrational spectroscopy imaging for the analysis, monitoring and characterisation of crops and plants. Molecules 2016, 21, 755. [CrossRef]

149. Barba, F.J.; Roohinejad, S.; Ishikawa, K.; Leong, S.Y.; El-Din A Bekhit, A.; Saraiva, J.A.; Lebovka, N. Electron spin resonance as a tool to monitor the influence of novel processing technologies on food properties. Trends Food Sci. Technol. 2020, 100, 77-87. [CrossRef]

150. Ezeanaka, M.C.; Nsor-Atindana, J.; Zhang, M. Online Low-field Nuclear Magnetic Resonance (LF-NMR) and Magnetic Resonance Imaging (MRI) for Food Quality Optimization in Food Processing. Food Bioprocess Technol. 2019, 12, 1435-1451. [CrossRef]

151. Hassoun, A.; Carpena, M.; Prieto, M.A.; Simal-Gandara, J.; Özogul, F.; Özogul, Y.; Çoban, Ö.E.; Guðjónsdóttir, M.; Barba, F.J.; Marti-Quijal, F.J.; et al. Use of Spectroscopic Techniques to Monitor Changes in Food Quality during Application of Natural Preservatives: A Review. Antioxidants 2020, 9, 882. [CrossRef]

152. Wiercigroch, E.; Szafraniec, E.; Czamara, K.; Pacia, M.Z.; Majzner, K.; Kochan, K.; Kaczor, A.; Baranska, M.; Malek, K. Raman and infrared spectroscopy of carbohydrates: A review. Spectrochim. Acta Part A Mol. Biomol. Spectrosc. 2017, 185, 317-335. [CrossRef] [PubMed]

153. Wold, J.P. On-line and non-destructive measurement of core temperature in heat treated fish cakes by NIR hyperspectral imaging. Innov. Food Sci. Emerg. Technol. 2016, 33, 431-437. [CrossRef]

154. Gao, R.; Feng, X.; Li, W.; Yuan, L.; Ge, J.; Lu, D.; Chen, B.; Yu, G. Changes in properties of white shrimp (Litopenaeus vannamei) protein during thermal denaturation. Food Sci. Biotechnol. 2016, 25, 21-26. [CrossRef] [PubMed]

155. Herrero, A.M. Raman spectroscopy a promising technique for quality assessment of meat and fish: A review. Food Chem. 2008, 107, 1642-1651. [CrossRef]

156. Bouraoui, M.; Nakai, S.; Li-Chan, E. In situ investigation of protein structure in Pacific whiting surimi and gels using Raman spectroscopy. Food Res. Int. 1997, 30, 65-72. [CrossRef]

157. Lin, X.; Yang, W.; Xu, D.; Wang, L. Effect of electron irradiation and heat on the structure of hairtail surimi. Radiat. Phys. Chem. 2015, 114, 50-54. [CrossRef]

158. Zhang, L.; Zhang, F.; Wang, X. Changes of protein secondary structures of pollock surimi gels under high-temperature $\left(100{ }^{\circ} \mathrm{C}\right.$ and $\left.120^{\circ} \mathrm{C}\right)$ treatment. J. Food Eng. 2016, 171, 159-163. [CrossRef]

159. Uddin, M.; Ishizaki, S.; Okazaki, E.; Tanaka, M. Near-infrared reflectance spectroscopy for determining end-point temperature of heated fish and shellfish meats. J. Sci. Food Agric. 2002, 82, 286-292. [CrossRef] 
160. Skåra, T.; Stormo, S.K.; Skipnes, D.; Kondjoyan, A.; Sivertsen, A.; Gins, G.; Van Derlinden, E.; Valdramidis, V.P.; Van Impe, J.F.M. Estimation of surface temperature and thermal load in short-time heat treatment of surimi through reflectance spectroscopy and heat transfer modeling. J. Food Eng. 2014, 120, 75-80. [CrossRef]

161. Uddin, M.; Okazaki, E.; Uddin Ahmad, M.; Fukuda, Y.; Tanaka, M. Noninvasive NIR spectroscopy to verify endpoint temperature of kamaboko gel. LWT Food Sci. Technol. 2005, 38, 809-814. [CrossRef]

162. Stormo, S.K.; Sivertsen, A.H.; Heia, K.; Skipnes, D. Endpoint temperature of heat-treated surimi can be measured by visible spectroscopy. Food Control 2012, 26, 92-97. [CrossRef]

163. Uddin, M.; Okazaki, E.; Ahmad, M.U.; Fukuda, Y.; Tanaka, M. NIR spectroscopy: A non-destructive fast technique to verify heat treatment of fish-meat gel. Food Control 2006, 17, 660-664. [CrossRef]

164. Elmasry, G.; Nakauchi, S. Noninvasive sensing of thermal treatments of Japanese seafood products using imaging spectroscopy. Int. J. Food Sci. Technol. 2015, 50, 1960-1971. [CrossRef]

165. Ovissipour, M.; Rasco, B.; Tang, J.; Sablani, S. Kinetics of Protein Degradation and Physical Changes in Thermally Processed Atlantic Salmon (Salmo salar). Food Bioprocess Technol. 2017, 10, 1865-1882. [CrossRef]

166. Ovissipour, M.; Shiroodi, S.G.; Rasco, B.; Tang, J.; Sablani, S.S. Electrolyzed water and mild-thermal processing of Atlantic salmon (Salmo salar): Reduction of Listeria monocytogenes and changes in protein structure. Int. J. Food Microbiol. 2018, 276, 10-19. [CrossRef]

167. Shaikh, S.; O’Donnell, C. Applications of fluorescence spectroscopy in dairy processing: A review. Curr. Opin. Food Sci. 2017, 17, 16-24. [CrossRef]

168. Sahar, A.; ur Rahman, U.; Kondjoyan, A.; Portanguen, S.; Dufour, E. Monitoring of thermal changes in meat by synchronous fluorescence spectroscopy. J. Food Eng. 2016, 168, 160-165. [CrossRef]

169. Zhu, D.; Ji, B.; Eum, H.L.; Zude, M. Evaluation of the non-enzymatic browning in thermally processed apple juice by front-face fluorescence spectroscopy. Food Chem. 2009, 113, 272-279. [CrossRef]

170. Ali, H.; Saleem, M.; Ullah, R.; Khan, S.; Atta, B.M.; Bilal, M. Thermal Effects on Biochemical Signatures of UHT, Pasteurized and Domestically Boiled Buffalo Milk Detected by Synchronous Fluorescence Spectroscopy. J. Fluoresc. 2019, 29, 485-493. [CrossRef]

171. Xiang, B.Y.; Ngadi, M.O.; Simpson, B.K.; Simpson, M.V. Pulsed electric field induced structural modification of soy protein isolate as studied by fluorescence spectroscopy. J. Food Process. Preserv. 2011, 35, 563-570. [CrossRef]

172. Hu, L.; Ren, S.; Shen, Q.; Ye, X.; Chen, J.; Ling, J. Protein oxidation and proteolysis during roasting and in vitro digestion of fish (Acipenser gueldenstaedtii). J. Sci. Food Agric. 2018, 98, 5344-5351. [CrossRef] [PubMed]

173. Semedo Tavares, W.P.; Dong, S.; Jin, W.; Yang, Y.; Han, K.; Zha, F.; Zhao, Y.; Zeng, M. Effect of different cooking conditions on the profiles of Maillard reaction products and nutrient composition of hairtail (Thichiurus lepturus) fillets. Food Res. Int. 2018, 103, 390-397. [CrossRef] [PubMed]

174. Cropotova, J.; Mozuraityte, R.; Standal, I.B.; Rustad, T. A non-invasive approach to assess texture changes in sous-vide cooked Atlantic mackerel during chilled storage by fluorescence imaging. Food Control 2018, 92, 216-224. [CrossRef]

175. Cropotova, J.; Mozuraityte, R.; Standal, I.B.; Rustad, T. Assessment of lipid oxidation in Atlantic mackerel (Scomber scombrus) subjected to different antioxidant and sous-vide cooking treatments by conventional and fluorescence microscopy methods. Food Control 2019, 104, 1-8. [CrossRef]

176. Hassoun, A.; Cropotova, J.; Rustad, T.; Heia, K.; Lindberg, S.-K.; Nilsen, H. Use of Spectroscopic Techniques for a Rapid and Non-Destructive Monitoring of Thermal Treatments and Storage Time of Sous-Vide Cooked Cod Fillets. Sensors 2020, 20, 2410. [CrossRef]

177. Cao, H.; Fan, D.; Jiao, X.; Huang, J.; Zhao, J.; Yan, B.; Zhou, W.; Zhang, W.; Ye, W.; Zhang, H.; et al. Intervention of transglutaminase in surimi gel under microwave irradiation. Food Chem. 2018, 268, 378-385. [CrossRef]

178. Tsakanikas, P.; Karnavas, A.; Panagou, E.Z.; Nychas, G.J. A machine learning workflow for raw food spectroscopic classification in a future industry. Sci. Rep. 2020, 10, 11212. [CrossRef]

179. Bi, J.; Li, Y.; Cheng, S.; Dong, X.; Kamal, T.; Zhou, D.; Li, D.; Jiang, P.; Zhu, B.W.; Tan, M. Changes in Body Wall of Sea Cucumber (Stichopus japonicus) during a two-Step Heating Process Assessed by Rheology, LF-NMR, and Texture Profile Analysis. Food Biophys. 2016, 11, 257-265. [CrossRef]

180. Xia, K.; Xu, W.; Huang, L.; Song, Y.; Zhu, B.W.; Tan, M. Water dynamics of turbot flesh during frying, boiling, and stewing processes and its relationship with color and texture properties: Low-field NMR and MRI studies. J. Food Process. Preserv. 2018, 42, e13338. [CrossRef] 
181. Sun, S.; Wang, S.; Lin, R.; Cheng, S.; Yuan, B.; Wang, Z.; Tan, M. Effect of Different Cooking Methods on Proton Dynamics and Physicochemical Attributes in Spanish Mackerel Assessed by Low-Field NMR. Foods 2020, 9, 364. [CrossRef]

182. Wang, S.; Lin, R.; Cheng, S.; Tan, M. Water dynamics changes and protein denaturation in surf clam evaluated by two-dimensional LF-NMR T1-T2 relaxation technique during heating process. Food Chem. 2020, 320, 126622. [CrossRef] [PubMed]

183. Tintchev, F.; Kuhlmann, U.; Wackerbarth, H.; Töpfl, S.; Heinz, V.; Knorr, D.; Hildebrandt, P. Redox processes in pressurised smoked salmon studied by resonance Raman spectroscopy. Food Chem. 2009, 112, 482-486. [CrossRef]

184. Saraiva, C.; Vasconcelos, H.; de Almeida, J.M.M.M. A chemometrics approach applied to Fourier transform infrared spectroscopy (FTIR) for monitoring the spoilage of fresh salmon (Salmo salar) stored under modified atmospheres. Int. J. Food Microbiol. 2017, 241, 331-339. [CrossRef] [PubMed]

185. Ojagh, S.M.; Núñez-Flores, R.; López-Caballero, M.E.; Montero, M.P.; Gómez-Guillén, M.C. Lessening of high-pressure-induced changes in Atlantic salmon muscle by the combined use of a fish gelatin-lignin film. Food Chem. 2011, 125, 595-606. [CrossRef]

186. Dong, X.; Wang, J.; Raghavan, V. Effects of high-intensity ultrasound processing on the physiochemical and allergenic properties of shrimp. Innov. Food Sci. Emerg. Technol. 2020, 65, 102441. [CrossRef]

187. Martínez-Maldonado, M.A.; Velazquez, G.; Ramírez de León, J.A.; Borderías, A.J.; Moreno, H.M. Effect of high pressure processing on heat-induced gelling capacity of blue crab (Callinectes sapidus) meat. Innov. Food Sci. Emerg. Technol. 2020, 59, 102253. [CrossRef]

188. Larrea-Wachtendorff, D.; Tabilo-Munizaga, G.; Moreno-Osorio, L.; Villalobos-Carvajal, R.; Pérez-Won, M. Protein Changes Caused by High Hydrostatic Pressure (HHP): A Study Using Differential Scanning Calorimetry (DSC) and Fourier Transform Infrared (FTIR) Spectroscopy. Food Eng. Rev. 2015, 7, 222-230. [CrossRef]

189. Sone, I.; Olsen, R.L.; Sivertsen, A.H.; Eilertsen, G.; Heia, K. Classification of fresh Atlantic salmon (Salmo salar L.) fillets stored under different atmospheres by hyperspectral imaging. J. Food Eng. 2012, 109, 482-489. [CrossRef]

190. Ivorra, E.; Girón, J.; Sánchez, A.J.; Verdú, S.; Barat, J.M.; Grau, R. Detection of expired vacuum-packed smoked salmon based on PLS-DA method using hyperspectral images. J. Food Eng. 2013, 117, 342-349. [CrossRef]

191. Li, N.; Shen, Y.; Liu, W.; Mei, J.; Xie, J. Low-field NMR and MRI to analyze the effect of edible coating incorporated with MAP on qualities of half-smooth tongue sole (Cynoglossus semilaevis Günther) fillets during refrigerated storage. Appl. Sci. 2018, 8, 1391. [CrossRef]

192. De Aguiar Saldanha Pinheiro, A.C.; Urbinati, E.; Tappi, S.; Picone, G.; Patrignani, F.; Lanciotti, R.; Romani, S.; Rocculi, P. The impact of gas mixtures of Argon and Nitrous oxide (N2O) on quality parameters of sardine (Sardina pilchardus) fillets during refrigerated storage. Food Res. Int. 2019, 115, 268-275. [CrossRef] [PubMed]

193. Albertos, I.; Martín-Diana, A.B.; Cullen, P.J.; Tiwari, B.K.; Ojha, S.K.; Bourke, P.; Álvarez, C.; Rico, D. Effects of dielectric barrier discharge (DBD) generated plasma on microbial reduction and quality parameters of fresh mackerel (Scomber scombrus) fillets. Innov. Food Sci. Emerg. Technol. 2017, 44, 117-122. [CrossRef]

194. Carneiro, C.D.S.; Mársico, E.T.; Ribeiro, R.D.O.R.; Conte-Júnior, C.A.; Mano, S.B.; Augusto, C.J.C.; Oliveira De Jesus, E.F. Low-Field Nuclear Magnetic Resonance (LF NMR 1H) to assess the mobility of water during storage of salted fish (Sardinella brasiliensis). J. Food Eng. 2016, 169, 321-325. [CrossRef]

195. Collewet, G.; Bugeon, J.; Idier, J.; Quellec, S.; Quittet, B.; Cambert, M.; Haffray, P. Rapid quantification of muscle fat content and subcutaneous adipose tissue in fish using MRI. Food Chem. 2013, 138, 2008-2015. [CrossRef]

196. Herrero, A.; Carmona, P.; Jiménez-Colmenero, F.; Ruíz-Capillas, C. Application of Vibrational Spectroscopy to Elucidate Protein Conformational Changes Promoted by Thermal Treatment in Muscle-Based Food. In Reactions and Mechanisms in Thermal Analysis of Advanced Materials; Tiwari, A., Raj, B., Eds.; Wiley-Scrivener: Beverly, MA, USA, 2015; pp. 467-482.

197. Shao, J.-H.; Zou, Y.-F.; Xu, X.-L.; Wu, J.-Q.; Zhou, G.-H. Evaluation of structural changes in raw and heated meat batters prepared with different lipids using Raman spectroscopy. Food Res. Int. 2011, 44, 2955-2961. [CrossRef] 
198. Wang, S.F.; Smith, D.M. Dynamic Rheological Properties and Secondary Structure of Chicken Breast Myosin As Influenced by Isothermal Heating. J. Agric. Food Chem. 1994, 42, 1434-1439. [CrossRef]

199. Xu, X.L.; Han, M.Y.; Fei, Y.; Zhou, G.H. Raman spectroscopic study of heat-induced gelation of pork myofibrillar proteins and its relationship with textural characteristic. Meat Sci. 2011, 87, 159-164. [CrossRef]

200. Berhe, D.T.; Engelsen, S.B.; Hviid, M.S.; Lametsch, R. Raman spectroscopic study of effect of the cooking temperature and time on meat proteins. Food Res. Int. 2014, 66, 123-131. [CrossRef]

201. Porep, J.U.; Kammerer, D.R.; Carle, R. On-line application of near infrared (NIR) spectroscopy in food production. Trends Food Sci. Technol. 2015, 46, 211-230. [CrossRef]

202. Barth, A. Infrared spectroscopy of proteins. Biochim. Biophys. Acta Bioenerg. 2007, 1767, 1073-1101. [CrossRef]

203. Ellekjær, M.R.; Isaksson, T. Assessment of maximum cooking temperatures in previously heat treated beef. Part 1: Near infrared spectroscopy. J. Sci. Food Agric. 1992, 59, 335-343. [CrossRef]

204. González-Mohino, A.; Antequera, T.; Ventanas, S.; Caballero, D.; Mir-Bel, J.; Pérez-Palacios, T. Near-infrared spectroscopy-based analysis to study sensory parameters on pork loins as affected by cooking methods and conditions. J. Sci. Food Agric. 2018. [CrossRef] [PubMed]

205. Biancolillo, A.; Boqué, R.; Cocchi, M.; Marini, F. Data Fusion Strategies in Food Analysis. In Data Handling in Science and Technology; Cocchi, M., Ed.; Elsevier: Amsterdam, The Nederlands, 2019; Volume 31, pp. 271-310. ISBN 9780444639844.

206. Calabrò, E.; Magazù, S. Comparison Between Conventional Convective Heating and Microwave Heating: An FTIR Spectroscopy Study of the Effects of Microwave Oven Cooking of Bovine Breast Meat. J. Electromagn. Anal. Appl. 2012, 04, 433-439. [CrossRef]

207. Perez-Palacios, T.; Caballero, D.; González-Mohíno, A.; Mir-Bel, J.; Antequera, T. Near Infrared Reflectance spectroscopy to analyse texture related characteristics of sous vide pork loin. J. Food Eng. 2019, 263, 417-423. [CrossRef]

208. Kandpal, L.M.; Lee, H.; Kim, M.S.; Mo, C.; Cho, B.K. Hyperspectral reflectance imaging technique for visualization of moisture distribution in cooked chicken breast. Sensors 2013, 13, 13289-13300. [CrossRef]

209. Liu, Y.; Sun, D.; Cheng, J.-H.; Han, Z. Hyperspectral Imaging Sensing of Changes in Moisture Content and Color of Beef During Microwave Heating Process. Food Anal. Methods 2018, 11, 2472-2484. [CrossRef]

210. O'Farrell, M.; Bakke, K.A.H.; Tschudi, J.; Wold, J.P. Near-infrared (NIR) interactance system for non-contact monitoring of the temperature profile of baked liver pâté. Appl. Spectrosc. 2011, 65, 1372-1379. [CrossRef]

211. Wold, J.P.; O'Farrell, M.; Tschudi, J.; Eskildsen, C.E.; Andersen, P.V.; Ottestad, S. In-line and non-destructive monitoring of core temperature in sausages during industrial heat treatment by NIR interaction spectroscopy. J. Food Eng. 2020, 277, 109921. [CrossRef]

212. Sahar, A.; Boubellouta, T.; Portanguen, S.; Kondjoyan, A.; Dufour, É. Synchronous front-face fluorescence spectroscopy coupled with parallel factors (PARAFAC) analysis to study the effects of cooking time on meat. J. Food Sci. 2009, 74, E534-E539. [CrossRef]

213. Sahar, A.; Portanguen, S.; Dufour, A.K.É. Potential of synchronous fuorescence spectroscopy coupled with chemometrics to determine the heterocyclic aromatic amines in grilled meat. Eur. Food Res. Technol. 2010, 231, 803-812. [CrossRef]

214. Yamaguchi, K.; Nomi, Y.; Homma, T.; Kasai, M.; Otsuka, Y. Determination of furosine and fluorescence as markers of the maillard reaction for the evaluation of meat products during actual cooking conditions. Food Sci. Technol. Res. 2012, 18, 67-76. [CrossRef]

215. Mitra, B.; Lametsch, R.; Akcan, T.; Ruiz-Carrascal, J. Pork proteins oxidative modifications under the influence of varied time-temperature thermal treatments: A chemical and redox proteomics assessment. Meat Sci. 2018, 140, 134-144. [CrossRef]

216. Trevisan, A.J.B.; de Almeida Lima, D.; Sampaio, G.R.; Soares, R.A.M.; Markowicz Bastos, D.H. Influence of home cooking conditions on Maillard reaction products in beef. Food Chem. 2016, 196, 161-169. [CrossRef] [PubMed]

217. Ferreira, V.C.S.; Morcuende, D.; Madruga, M.S.; Silva, F.A.P.; Estévez, M. Role of protein oxidation in the nutritional loss and texture changes in ready-to-eat chicken patties. Int. J. Food Sci. Technol. 2018, 53, 1518-1526. [CrossRef]

218. Sun, H.X.; Huang, F.; Ding, Z.J.; Zhang, C.J.; Zhang, L.; Zhang, H. Low-field nuclear magnetic resonance analysis of the effects of heating temperature and time on braised beef. Int. J. Food Sci. Technol. 2017, 52, 1193-1202. [CrossRef] 
219. Han, Z.; Zhang, J.; Zheng, J.; Li, X.; Shao, J.H. The study of protein conformation and hydration characteristics of meat batters at various phase transition temperatures combined with Low-field nuclear magnetic resonance and Fourier transform infrared spectroscopy. Food Chem. 2019, 280, 263-269. [CrossRef]

220. Wackerbarth, H.; Kuhlmann, U.; Tintchev, F.; Heinz, V.; Hildebrandt, P. Structural changes of myoglobin in pressure-treated pork meat probed by resonance Raman spectroscopy. Food Chem. 2009, 115, 1194-1198. [CrossRef]

221. Sazonova, S.; Grube, M.; Shvirksts, K.; Galoburda, R.; Gramatina, I. FTIR spectroscopy studies of high pressure-induced changes in pork macromolecular structure. J. Mol. Struct. 2019, 1186, 377-383. [CrossRef]

222. Pavli, F.; Argyri, A.A.; Nychas, G.J.E.; Tassou, C.; Chorianopoulos, N. Use of Fourier transform infrared spectroscopy for monitoring the shelf life of ham slices packed with probiotic supplemented edible films after treatment with high pressure processing. Food Res. Int. 2018, 106, 1061-1068. [CrossRef]

223. Ammor, M.S.; Argyri, A.; Nychas, G.J.E. Rapid monitoring of the spoilage of minced beef stored under conventionally and active packaging conditions using Fourier transform infrared spectroscopy in tandem with chemometrics. Meat Sci. 2009, 81, 507-514. [CrossRef]

224. Bertram, H.C.; Aaslyng, M.D.; Andersen, H.J. Elucidation of the relationship between cooking temperature, water distribution and sensory attributes of pork-A combined NMR and sensory study. Meat Sci. 2005, 70, 75-81. [CrossRef] [PubMed]

225. Berhe, D.T.; Lawaetz, A.J.; Engelsen, S.B.; Hviid, M.S.; Lametsch, R. Accurate determination of endpoint temperature of cooked meat after storage by Raman spectroscopy and chemometrics. Food Control 2015, 52, 119-125. [CrossRef]

226. Bouhrara, M.; Clerjon, S.; Damez, J.L.; Kondjoyan, A.; Bonny, J.M. In situ imaging highlights local structural changes during heating: The case of meat. J. Agric. Food Chem. 2012, 60, 4678-4687. [CrossRef] [PubMed]

227. Han, M.; Wang, P.; Xu, X.; Zhou, G. Low-field NMR study of heat-induced gelation of pork myofibrillar proteins and its relationship with microstructural characteristics. Food Res. Int. 2014, 62, 1175-1182. [CrossRef]

228. Schmidt, H.; Scheier, R.; Hopkins, D.L. Preliminary investigation on the relationship of Raman spectra of sheep meat with shear force and cooking loss. Meat Sci. 2013, 93, 138-143. [CrossRef]

229. Durek, J.; Bolling, J.S.; Knorr, D.; Schwägele, F.; Schlüter, O. Effects of different storage conditions on quality related porphyrin fluorescence signatures of pork slices. Meat Sci. 2012, 90, 252-258. [CrossRef]

230. Yang, H.; Hopkins, D.L.; Zhang, Y.; Zhu, L.; Dong, P.; Wang, X.; Mao, Y.; Luo, X.; Fowler, S.M. Preliminary investigation of the use of Raman spectroscopy to predict beef spoilage in different types of packaging. Meat Sci. 2020, 165, 108136. [CrossRef]

231. Sinelli, N.; Limbo, S.; Torri, L.; Di Egidio, V.; Casiraghi, E. Evaluation of freshness decay of minced beef stored in high-oxygen modified atmosphere packaged at different temperatures using NIR and MIR spectroscopy. Meat Sci. 2010, 86, 748-752. [CrossRef]

232. Miyaoka, R.; Ando, M.; Harada, R.; Osaka, H.; Samuel, A.Z.; Hosokawa, M.; Takeyama, H. Rapid inspection method for investigating the heat processing conditions employed for chicken meat using Raman spectroscopy. J. Biosci. Bioeng. 2020, 129, 700-705. [CrossRef]

233. Spanos, D.; Christensen, M.; Tørngren, M.A.; Baron, C.P. Visible spectroscopy as a tool for the assessment of storage conditions of fresh pork packaged in modified atmosphere. Meat Sci. 2016, 113, 154-161. [CrossRef]

234. Sarangapani, C.; Ryan Keogh, D.; Dunne, J.; Bourke, P.; Cullen, P.J. Characterisation of cold plasma treated beef and dairy lipids using spectroscopic and chromatographic methods. Food Chem. 2017, 235, 324-333. [CrossRef] [PubMed]

235. Kang, D.C.; Zou, Y.H.; Cheng, Y.P.; Xing, L.J.; Zhou, G.H.; Zhang, W.G. Effects of power ultrasound on oxidation and structure of beef proteins during curing processing. Ultrason. Sonochem. 2016, 33, 47-53. [CrossRef]

236. Flores, D.R.M.; Brasil, C.C.B.; Campagnol, P.C.B.; Jacob-Lopes, E.; Zepka, L.Q.; Wagner, R.; Menezes, C.R.; Barin, J.S.; Flores, E.M.M.; Cichoski, A.J. Application of ultrasound in chicken breast during chilling by immersion promotes a fast and uniform cooling. Food Res. Int. 2018, 109, 59-64. [CrossRef] [PubMed]

237. Shi, H.; Zhang, X.; Chen, X.; Fang, R.; Zou, Y.; Wang, D.; Xu, W. How ultrasound combined with potassium alginate marination tenderizes old chicken breast meat: Possible mechanisms from tissue to protein. Food Chem. 2020, 328, 127144. [CrossRef] [PubMed] 
238. Zhang, S.; Yang, R.; Zhao, W.; Liang, Q.; Zhang, Z. The first ESR observation of radical species generated under pulsed electric fields processing. LWT Food Sci. Technol. 2011, 44, 1233-1235. [CrossRef]

239. Bolumar, T.; Andersen, M.L.; Orlien, V. Antioxidant active packaging for chicken meat processed by high pressure treatment. Food Chem. 2011, 129, 1406-1412. [CrossRef]

240. Bolumar, T.; Andersen, M.L.; Orlien, V. Mechanisms of radical formation in beef and chicken meat during high pressure processing evaluated by electron spin resonance detection and the addition of antioxidants. Food Chem. 2014, 150, 422-428. [CrossRef]

241. Bolumar, T.; Skibsted, L.H.; Orlien, V. Kinetics of the formation of radicals in meat during high pressure processing. Food Chem. 2012, 134, 2114-2120. [CrossRef]

242. O'Dowd, L.P.; Arimi, J.M.; Noci, F.; Cronin, D.A.; Lyng, J.G. An assessment of the effect of pulsed electrical fields on tenderness and selected quality attributes of post rigour beef muscle. Meat Sci. 2013, 93, 303-309. [CrossRef]

243. Mungure, T.E.; Farouk, M.M.; Birch, E.J.; Carne, A.; Staincliffe, M.; Stewart, I.; Bekhit, A.E.-D.A. Effect of PEF treatment on meat quality attributes, ultrastructure and metabolite profiles of wet and dry aged venison Longissimus dorsi muscle. Innov. Food Sci. Emerg. Technol. 2020, 65, 102457. [CrossRef]

(C) 2020 by the authors. Licensee MDPI, Basel, Switzerland. This article is an open access article distributed under the terms and conditions of the Creative Commons Attribution (CC BY) license (http://creativecommons.org/licenses/by/4.0/). 